\title{
Review Article \\ Oil and Gas Production Wastewater: Soil Contamination and Pollution Prevention
}

\author{
John Pichtel \\ Natural Resources and Environmental Management, Ball State University, Muncie, IN 47306, USA \\ Correspondence should be addressed to John Pichtel; jpichtel@bsu.edu
}

Received 25 November 2015; Accepted 14 February 2016

Academic Editor: Ezio Ranieri

Copyright (C) 2016 John Pichtel. This is an open access article distributed under the Creative Commons Attribution License, which permits unrestricted use, distribution, and reproduction in any medium, provided the original work is properly cited.

During oil and natural gas production, so-called "produced water" comprises the largest byproduct stream. In addition, many oil and gas operations are augmented via injection of hydraulic fracturing (HF) fluids into the formation. Both produced water and HF fluids may contain hundreds of individual chemicals, some known to be detrimental to public health and the environment. Oil and gas production wastewater may serve a range of beneficial purposes, particularly in arid regions, if managed correctly. Numerous treatment technologies have been developed that allow for injection, discharge to the land surface, or beneficial reuse. Although many papers have addressed the effects of oil and gas production wastewater (OGPW) on groundwater and surface water quality, significantly less information is available on the effects of these fluids on the soil resource. This review paper compiles fundamental information on numerous chemicals used and produced during oil and gas development and their effects on the soil environment. Additionally, pollution prevention technologies relating to OGPW are presented. An understanding of the effects of OGPW on soil chemical, physical, and biological properties can provide a foundation for effective remediation of OGPW-affected soils; additionally, sustainable reuse of oil and gas water for irrigation and industrial purposes may be enhanced.

\section{Introduction}

Production of conventional oil and gas and coal bed methane is often accompanied by production of large volumes of produced water. The United States generates an estimated 21 billion barrels of produced water every year [1].

In certain geologic strata substantial volumes of oil and natural gas are present, yet they experience poor recovery rates due to low permeability of local strata. This is especially true for shales, tight sands, oil sands, and coal beds [2]. In hydraulic fracturing (HF) ("fracking"), a specially tailored mixture of fluids is pumped into recovery wells under high pressure to fracture low permeability formations and enhance gas and oil production [3-5]. Extraction of hydrocarbon resources using HF is commonly referred to as "unconventional production." Unconventional wells include those drilled horizontally, allowing the borehole to bend 90 degrees and penetrate the target formation laterally up to thousands of meters [6]. Within the past two decades the combination of HF with horizontal drilling has opened immense new oil and gas reserves worldwide which were previously considered inaccessible or unprofitable $[7,8]$ and brought large-scale drilling to new regions $[3,9]$.

Hydraulic fracturing is performed at depths between 5,000 and 10,000 feet and requires 2,500,000-4,200,000 gallons of water per well [10]. Fracturing operations inject highly pressurized fluids, that is, between 2,000 and $12,000 \mathrm{psi}$, at an average flow rate of $2000 \mathrm{gpm}(47 \mathrm{bbl} / \mathrm{min})$ [11]. The water is mixed with $0.5-2.0 \%$ (by volume) of selected chemical additives to increase water flow and improve deposition efficiency. Approximately 1,000 chemicals are known to be used in the HF process $[7,11]$.

Following initial injection into the well to generate fractures, a portion of the injected water returns to the surface immediately and is termed "flowback" [3]. The remaining fluids either permeate into the formation or return to the surface over the life of the producing well and are termed "produced water." Both types of wastewater may contain HF fluids, naturally occurring salts, radioactive materials, heavy metals, and other compounds from the formation such as polycyclic aromatic hydrocarbons, alkenes, alkanes, and other volatile and semivolatile organics [12-18]. In this 
paper, oil and gas flowback water, produced water, and hydraulic fracturing fluids will collectively be termed oil and gas production wastewater (OGPW).

As HF operations are expanding, the volumes of wastewater being generated are increasing exponentially [19]. Wastewater from drilling activities is typically managed via disposal in injection wells or evaporation ponds, application to fields, spreading on roads, and/or treatment and reuse for future oil and gas operations $[8,13,20,21]$.

Hydraulic fracturing components may pose a threat to public health and the environment as some are known to be acutely toxic, some are carcinogenic, and others are believed to be endocrine-disruptors [12, 22-24]. Other chemicals remain proprietary information [25] whose effects on public health and the environment are unavailable. Recent work found that $67 \%, 37 \%$, and $18 \%$ of assessed wells were fractured with $\geq 1,5$, or 10 proprietary chemicals, respectively $[12,26]$.

Contamination of soil can occur through spills of fluids during drilling and fracturing processes and during transport by truck or through wastewater pipelines and failure of well casings and equipment failures and corrosion of pipes and tanks. In some regions OGPW is transferred to wastewater treatment plants [20]; however, facilities may be unable to remove several anthropogenic or naturally occurring compounds [27-29]. This can result in their discharge, following treatment, to surface water and ultimately to soil $[30,31]$.

Between 2009 and 2013 a total of 1933 spills were documented in Colorado [32]. In 2013, spills were reported at 1\% of Colorado wells (550 of 51,000 active wells). An analysis of permitted Pennsylvania wells shows a spill rate of 2\% (103 of 5,580 active wells) [26]. A total of 24 states with active shale reservoirs currently report spills; however, reporting limits and information required vary markedly. Only five states require maintenance of public records for spills and violations $[12,26,33]$. In light of the limited mandatory reporting, it is possible that the degree of oil and gas operations on water quality is underestimated [26,33]. For example, an analysis in Pennsylvania found that only $59 \%$ of documented spills were reported $[12,26]$. Elevated concentrations of benzene, toluene, ethylbenzene, and xylenes (BTEX) have been detected in groundwater near surface spills $[34,35]$; soils have been affected by excess salinity and sodicity $[36,37]$.

A great number of papers have described the effects of OGPW on groundwater $[14,38-40]$ and surface water [4042]; however, studies of the effects of OGPW on the soil resource are scant, and reclamation of OGPW-affected soils has received minimal attention in the scientific literature. In order to understand the potential effects of OGPW on soil chemical, physical, and biological properties as well as potential effects on plant growth, it is necessary to identify the chemicals used in HF and those produced from active wells, as well as their behavior in soil. The objectives of this paper are to cite common chemicals that are used for, and produced during, oil and gas development and compile essential information on their effects on the soil environment. Additionally, both remediation of OGPW-affected soils and pollution prevention technologies will be presented.

\section{Hydraulic Fracturing Fluids}

Oil and gas production chemicals can be pure compounds or mixtures containing active ingredients dissolved in a solvent or cosolvent and used to serve numerous processes (Table 1) [53].

In response to concerns about the potential public health and environmental impacts associated with HF, key reagents have, in recent years, been compiled and made publicly available. Regulatory agencies in many states have established reporting requirements for unconventional production; however, not all such requirements are mandatory [54, 55]. Many oil and gas producers choose to publish lists of HF chemicals on company websites or in the FracFocus Chemical Disclosure Registry [56].

The broad categories of HF fluids in routine use consist of [57] (1) viscosified water-based fluids; (2) nonviscosified water-based fluids; (3) gelled oil-based fluids; (4) acid-based fluids; and (5) foam fluids. For many hydrocarbon reservoirs, water-based fluids are most suitable due to the historic ease with which large volumes of mix water can be acquired.

Hydraulic fracturing fluids contain approximately 98 to $99.5 \%$ water plus a specially prepared mixture that helps optimize the fracturing process $[3,56]$. Typical additives include proppants (propping agents), gelling and foaming components, friction reducers, cross-linkers, breakers, $\mathrm{pH}$ adjusters, biocides, corrosion inhibitors, scale inhibitors, iron controlling compounds, clay stabilizers, and surfactants (Table 1) $[46,58]$. Not all these additives are used in every fracturing project, and sometimes one class of additives can serve multiple purposes; that is, a surfactant can be used as a cross-linker and gelling agent in certain situations [46]. Chemicals are added throughout the entire production process including drilling and fracturing and through closure to serve numerous functions $[7,13]$. Some common HF additives are listed in Table 2.

A comprehensive study of the properties of HF chemicals was carried out by Stringfellow et al. [46] and includes commonly used compounds for each class of agents as well as data for toxicity and biodegradability.

2.1. Proppants. Propping agents are employed to "prop open" the fracture once pumps are turned off and fractures begin to close. The ideal propping agent is resistant to crushing and to corrosion, of low density, and is readily available and inexpensive [59]. Common propping agents are silica sand, resin-coated sand (RCS), and ceramic proppants (e.g., sintered bauxite, intermediate-strength proppant [ISP], and lightweight proppant [LWP]) [60]. Generally, sand is used to prop open fractures in shallow formations. RCS is stronger than sand and is used where more compressive strength is required to minimize proppant crushing. Ceramic proppants are used to stimulate deep $(>8,000 \mathrm{ft}$ ) wells where significant in situ stresses impart large forces on the propping agent [61].

2.2. Gelling Agents. Gellants increase the viscosity of HF fluids. Greater viscosities increase fracture width so higher concentrations of proppant can be injected, fluid loss is 
TABLE 1: Common classes of hydraulic fracturing compounds and their uses.

\begin{tabular}{|c|c|c|}
\hline Chemical category & Application in hydraulic fracturing & Example compounds \\
\hline Proppants & $\begin{array}{l}\text { Hold fissures open and allow gas to flow out of the } \\
\text { formation }\end{array}$ & $\begin{array}{l}\text { Sand, sintered bauxite, zirconium oxide, ceramic beads, } \\
\text { and graphite }\end{array}$ \\
\hline Gellants & $\begin{array}{l}\text { Increase viscosity and suspend sand during proppant } \\
\text { transport }\end{array}$ & $\begin{array}{l}\text { Propylene glycol, guar gum, ethylene glycol, and } \\
\text { petroleum distillate }\end{array}$ \\
\hline Foamers & $\begin{array}{l}\text { Increase carrying capacity while transporting } \\
\text { proppants and decrease overall volume of fluid needed }\end{array}$ & 2-Butoxyethanol, diethylene glycol \\
\hline Cross-linkers & $\begin{array}{l}\text { Thicken fluids to increase viscosity and proppant } \\
\text { transport into fractures }\end{array}$ & $\begin{array}{l}\text { Potassium hydroxide, ethylene glycol, borate salts, and } \\
\text { petroleum distillates }\end{array}$ \\
\hline Breakers & $\begin{array}{l}\text { Reduce the viscosity of the fluid so proppant will flow } \\
\text { into fractures; added near the end of hydraulic } \\
\text { fracturing to enhance flowback }\end{array}$ & Ammonium persulfate, magnesium peroxide \\
\hline Acids & $\begin{array}{l}\text { Clean up cement and drilling mud before fracturing } \\
\text { fluid is injected and clear the path through the } \\
\text { formation. Used later to dissolve minerals and clays to } \\
\text { reduce clogging, allowing gas to flow to the surface }\end{array}$ & Hydrochloric acid \\
\hline $\mathrm{pH}$ control & $\begin{array}{l}\text { Maintains } \mathrm{pH} \text { at various stages to ensure maximum } \\
\text { effectiveness of various additives }\end{array}$ & Sodium hydroxide, acetic acid \\
\hline Biocides & $\begin{array}{l}\text { Kill bacteria that produce gases (particularly } \mathrm{H}_{2} \mathrm{~S} \text { ) } \\
\text { which could contaminate methane gas, corrode pipes } \\
\text { and fittings, and break down gellants }\end{array}$ & Glutaraldehyde, 2-bromo-2-nitro-1,2-propanediol \\
\hline Corrosion inhibitors & Reduce damage to steel from acidic HF fluids & Ethoxylated octylphenol and nonylphenol, isopropanol \\
\hline Scale inhibitors & $\begin{array}{l}\text { Prevent buildup of mineral scale that can block fluid } \\
\text { and gas passage through the pipes. Prevent steel } \\
\text { materials from being damaged by acidic fracking fluids }\end{array}$ & $\begin{array}{l}\text { Acrylamide, sodium polycarboxylate, methanol, and } \\
\text { ammonium bisulfate }\end{array}$ \\
\hline Iron control & $\begin{array}{l}\text { Prevents carbonate and sulfate compounds from } \\
\text { precipitating to form plugs in shale formation }\end{array}$ & Ammonium chloride, ethylene glycol, and polyacrylate \\
\hline Clay stabilizers & $\begin{array}{l}\text { Block clays from swelling to block the open channels } \\
\text { created in the mining operation }\end{array}$ & Tetramethyl ammonium chloride, sodium chloride \\
\hline Defoamers & $\begin{array}{l}\text { Reduce foaming after it is no longer needed; lowers } \\
\text { surface tension; and allows trapped gas to escape }\end{array}$ & 2-Ethylhexanol, oleic acid, and oxalic acid \\
\hline Friction reducers & $\begin{array}{l}\text { To make water slick and minimize the friction created } \\
\text { under high pressure and to increase the rate and } \\
\text { efficiency of moving the HF fluid }\end{array}$ & $\begin{array}{l}\text { Acrylamide, ethylene glycol, petroleum distillate, } \\
\text { methanol, sodium acrylate-acrylamide copolymer, } \\
\text { polyacrylamide (PAM), and petroleum distillates }\end{array}$ \\
\hline Surfactants & $\begin{array}{l}\text { Reduce surface tension and improve fluid passage } \\
\text { through pipes in either direction }\end{array}$ & $\begin{array}{l}\text { Methanol, ethanol, isopropanol, naphthalene, } \\
\text { 1,2,4-trimethylbenzene, and 2-butoxyethanol }\end{array}$ \\
\hline
\end{tabular}

$[3,12,43-45]$.

reduced, proppant transport is improved, and friction pressure is reduced [62].

Gelling agents primarily consist of guar and derivatives (e.g., hydroxypropyl guar, carboxymethyl guar, and carboxymethyl hydroxypropyl guar), celluloses, acids, and alcohols $[62,63]$. Gellants can be linear or cross-linked to increase fluid viscosity. Agents are selected based on sitespecific conditions in the well including temperature and salinity $[5,46]$.

Diesel fuel is sometimes used to form a viscous HF gel when combined with guar concentrate. The US Environmental Protection Agency (US EPA) has attempted to regulate the use of diesel fuel in HF; however, it is still used in place of water as it can carry more guar concentrate per unit volume [43].

2.3. Friction Reducers. Friction reducers are sometimes used as an alternative to gelling agents. The most commonly used friction reducer is 2-propenamide (polyacrylamide,
$\left.\left[\mathrm{C}_{3} \mathrm{H}_{5} \mathrm{NO}\right]_{n}\right)[46]$. Friction reducers are water-soluble, nonvolatile, and nontoxic.

2.4. Cross-linkers. Cross-linkers bind gel molecules and thereby increase viscosity and proppant transport. Crosslinkers frequently used in HF include borate salts; titanium, zirconium, and aluminum compounds; monoethanolamine; and monoethylamine [5, 47, 56]. Ammonium chloride, ethylene glycol, and potassium hydroxide are also used. Concentrations of cross-linkers in HF fluid are relatively low and range from 0.5 to $250 \mathrm{mg} / \mathrm{L}$ [47, 64-67]. Borate ions are the most commonly used cross-linking agents for guar polymer applications [68]. Borax (sodium tetraborate decahydrate) and boric acid plus caustic soda and crosslinking agents $(0.024-0.09 \% \mathrm{w} / \mathrm{w})$ have been used as sources of borate ions to cross-link guar [68].

2.5. Breakers. The viscous HF fluid, whether cross-linked or linear, must be degraded in order to achieve high conductivity 
TABLE 2: Chemicals and chemical mixtures identified as being commonly used in hydraulic fracturing based on available sources.

\begin{tabular}{|c|c|c|}
\hline Chemical name & CAS number & Formula \\
\hline Acetaldehyde & $75-07-0$ & $\mathrm{C}_{2} \mathrm{H}_{4} \mathrm{O}$ \\
\hline Acetic acid & $64-19-7$ & $\mathrm{C}_{2} \mathrm{H}_{4} \mathrm{O}_{2}$ \\
\hline Acetone & $67-64-1$ & $\mathrm{C}_{3} \mathrm{H}_{6} \mathrm{O}$ \\
\hline Adipic acid & $124-04-9$ & $\mathrm{C}_{6} \mathrm{H}_{10} \mathrm{O}_{4}$ \\
\hline $\begin{array}{l}\text { Alkyl benzyl dimethyl } \\
\text { ammonium chloride }\end{array}$ & $68424-85-1$ & Various \\
\hline Ammonium chloride & $12125-02-9$ & $\mathrm{ClH}_{4} \mathrm{~N}$ \\
\hline Ammonium persulfate & $7727-54-0$ & $\left(\mathrm{NH}_{4}\right)_{2} \mathrm{~S}_{2} \mathrm{O}_{8}$ \\
\hline Ammonium sulfate & $7783-20-2$ & $\left(\mathrm{NH}_{4}\right)_{2} \mathrm{SO}_{4}$ \\
\hline Borate salts & Various & Various \\
\hline Boric acid sodium salt & $1333-73-9$ & $\mathrm{Na}_{3} \mathrm{BO}_{3}$ \\
\hline Calcium chloride & $10043-52-4$ & $\mathrm{CaCl}_{2}$ \\
\hline Calcium peroxide & $1305-79-9$ & $\mathrm{CaO}_{2}$ \\
\hline Carbon dioxide & $124-38-9$ & $\mathrm{CO}_{2}$ \\
\hline Carboxymethyl guar & $39346-76-4$ & Various \\
\hline $\begin{array}{l}\text { Carboxymethyl hydroxyethyl } \\
\text { cellulose }\end{array}$ & $9004-30-2$ & Various \\
\hline $\begin{array}{l}\text { Carboxymethyl hydroxypropyl } \\
\text { guar }\end{array}$ & $68130-15-4$ & Various \\
\hline Choline chloride & $67-48-1$ & $\mathrm{C}_{5} \mathrm{H}_{14} \mathrm{ClNO}$ \\
\hline Citric acid & $77-92-9$ & $\mathrm{C}_{6} \mathrm{H}_{8} \mathrm{O}_{7}$ \\
\hline $\begin{array}{l}\text { Copolymer of acrylamide and } \\
\text { sodium acrylate }\end{array}$ & $25987-30-8$ & Various \\
\hline Copper compounds & Various & Various \\
\hline $\begin{array}{l}\text { Didecyl dimethyl ammonium } \\
\text { chloride }\end{array}$ & $7173-51-5$ & $\mathrm{C}_{22} \mathrm{H}_{48} \mathrm{ClN}$ \\
\hline Diesel fuel & Various & Various \\
\hline Diethanolamine & $111-42-2$ & $\mathrm{C}_{4} \mathrm{H}_{11} \mathrm{NO}_{2}$ \\
\hline $\begin{array}{l}\text { Dimethyl dihydrogenated tallow } \\
\text { ammonium chloride }\end{array}$ & Various & Various \\
\hline Ester salt & Various & Various \\
\hline Ethanol & $64-17-5$ & $\mathrm{C}_{2} \mathrm{H}_{6} \mathrm{O}$ \\
\hline Ethyl methyl derivatives & Various & Various \\
\hline Ethylene glycol & $107-21-1$ & $\mathrm{C}_{2} \mathrm{H}_{6} \mathrm{O}_{2}$ \\
\hline Formic acid & $64-18-6$ & $\mathrm{CH}_{2} \mathrm{O}_{2}$ \\
\hline Fumaric acid & $110-17-8$ & $\mathrm{C}_{4} \mathrm{H}_{4} \mathrm{O}_{4}$ \\
\hline Glutaraldehyde & $111-30-8$ & $\mathrm{C}_{5} \mathrm{H}_{8} \mathrm{O}$ \\
\hline Glycol ethers & Various & Various \\
\hline Guar gum & $9000-30-0$ & Various \\
\hline Isopropanol & $67-63-0$ & $\mathrm{C}_{3} \mathrm{H}_{8} \mathrm{O}$ \\
\hline Magnesium oxide & $1309-48-4$ & $\mathrm{MgO}$ \\
\hline Magnesium peroxide & $14452-57-4$ & $\mathrm{MgO}_{2}$ \\
\hline Methanol & $67-56-1$ & $\mathrm{CH}_{4} \mathrm{O}$ \\
\hline Monoethanolamine & $141-43-5$ & $\mathrm{C}_{2} \mathrm{H}_{7} \mathrm{NO}$ \\
\hline Monoethylamine & 75-04-7 & $\mathrm{C}_{2} \mathrm{H}_{7} \mathrm{~N}$ \\
\hline$N, n$-Dimethyl formamide & $68-12-2$ & $\mathrm{C}_{3} \mathrm{H}_{7} \mathrm{NO}$ \\
\hline Naphthalene & $91-20-3$ & $\mathrm{C}_{10} \mathrm{H}_{8}$ \\
\hline Nitrogen & $7727-37-9$ & $\mathrm{~N}_{2}$ \\
\hline Petroleum distillate & $64741-85-1$ & Various \\
\hline Phosphonic acid salt & Various & Various \\
\hline Polyacrylamide & $9003-05-8$ & $\left(\mathrm{C}_{3} \mathrm{H}_{5} \mathrm{NO}\right)_{n}$ \\
\hline Polyglycol ether & Various & Various \\
\hline Potassium carbonate & $584-08-7$ & $\mathrm{~K}_{2} \mathrm{CO}_{3}$ \\
\hline
\end{tabular}

TABLE 2: Continued.

\begin{tabular}{|c|c|c|}
\hline Chemical name & CAS number & Formula \\
\hline Potassium chloride & $7447-40-7$ & $\mathrm{KCl}$ \\
\hline Potassium hydroxide & $1310-58-3$ & $\mathrm{KOH}$ \\
\hline Potassium metaborate & $13709-94-9$ & $\mathrm{BKO}_{2}$ \\
\hline Potassium persulfate & $7727-21-1$ & $\mathrm{~K}_{2} \mathrm{O}_{8} \mathrm{~S}_{2}$ \\
\hline Propargyl alcohol & $107-19-7$ & $\mathrm{C}_{3} \mathrm{H}_{4} \mathrm{O}$ \\
\hline Pyridinium & $16969-45-2$ & $\mathrm{C}_{5} \mathrm{H}_{6} \mathrm{~N}$ \\
\hline Quaternary ammonium chloride & $61789-71-1$ & Various \\
\hline Sodium carbonate & $497-19-8$ & $\mathrm{Na}_{2} \mathrm{CO}_{3}$ \\
\hline Sodium chloride & $7647-14-5$ & $\mathrm{NaCl}$ \\
\hline Sodium erythorbate & $6381-77-7$ & $\mathrm{C}_{6} \mathrm{H}_{7} \mathrm{NaO}_{6}$ \\
\hline Sodium hydroxide & $1310-73-2$ & $\mathrm{NaOH}$ \\
\hline Sodium lauryl sulfate & $151-21-3$ & $\mathrm{C}_{12} \mathrm{H}_{25} \mathrm{NaO}_{4} \mathrm{~S}$ \\
\hline Sodium persulfate & $7775-27-1$ & $\mathrm{Na}_{2} \mathrm{O}_{8} \mathrm{~S}_{2}$ \\
\hline Sodium polycarboxylate & Various & Various \\
\hline Sodium tetraborate decahydrate & $1303-96-4$ & $\mathrm{~B}_{4} \mathrm{O}_{7} \cdot 2 \mathrm{Na} \cdot 10 \mathrm{H}_{2} \mathrm{O}$ \\
\hline $\begin{array}{l}\text { Tetrakis hydroxymethyl } \\
\text { phosphonium sulfate }\end{array}$ & $55566-30-8$ & $\left(\mathrm{C}_{4} \mathrm{H}_{12} \mathrm{O}_{4} \mathrm{P}\right)_{2} \mathrm{O}_{4} \mathrm{~S}$ \\
\hline Tetramethyl ammonium c & $75-$ & $\mathrm{C}_{4} \mathrm{H}_{12} \mathrm{ClN}$ \\
\hline Thioglycolic acid & $68-$ & $\mathrm{C}_{2} \mathrm{H}_{4} \mathrm{O}_{2} \mathrm{~S}$ \\
\hline Thiourea & $62-56-6$ & $\mathrm{CH}_{4} \mathrm{~N}_{2} \mathrm{~S}$ \\
\hline $\begin{array}{l}\text { Tributyl tetradecyl phosphonium } \\
\text { chloride }\end{array}$ & $81741-28-8$ & $\mathrm{C}_{26} \mathrm{H}_{56} \mathrm{PCl}$ \\
\hline Triethanolamine zirconate & 101033-44-7 & $\mathrm{C}_{24} \mathrm{H}_{56} \mathrm{~N}_{4} \mathrm{O}_{12} \mathrm{Zr}$ \\
\hline $\begin{array}{l}\text { Zirconium hydroxy lactate } \\
\text { sodium complex }\end{array}$ & $113184-20-6$ & $\mathrm{C}_{12} \mathrm{H}_{19} \mathrm{NaO}_{16} \mathrm{Zr}$ \\
\hline Zirconium nitrate & $13746-89-9$ & $\mathrm{Zr}\left(\mathrm{NO}_{3}\right)_{4}$ \\
\hline Zirconium sulfate & $14644-61-2$ & $\mathrm{Zr}\left(\mathrm{SO}_{4}\right)_{2}$ \\
\hline $\begin{array}{l}\text { 1-Bromo-3-chloro-5,5- } \\
\text { dimethylhydantoin }\end{array}$ & $16079-88-2$ & $\mathrm{C}_{5} \mathrm{H}_{6} \mathrm{BrClN}_{2} \mathrm{O}_{2}$ \\
\hline $\begin{array}{l}\text { 2,2-Dibromo-3- } \\
\text { nitrilopropionamide }\end{array}$ & $10222-01-2$ & $\mathrm{C}_{3} \mathrm{H}_{2} \mathrm{Br}_{2} \mathrm{~N}_{2} \mathrm{O}$ \\
\hline 2-Bromo-3-nitrilopropionamide & $1113-55-9$ & $\mathrm{C}_{3} \mathrm{H}_{3} \mathrm{BrN}_{2} \mathrm{O}$ \\
\hline 2-Butoxyethanol & $111-76-2$ & $\mathrm{C}_{6} \mathrm{H}_{14} \mathrm{O}_{2}$ \\
\hline
\end{tabular}

$[5,44,46-48]$.

in the proppant pack. Likewise, the filter cake formed on the face of the rock, which may restrict the flow of oil and gas and reduce well productivity, must be degraded. Breakers reverse cross-linking and cleave polymers into low molecular weight fragments thus reducing viscosity of gelled fluids $[46,69-71]$.

The general types of breakers are oxidizers, acids, and enzymes [62]. Oxidizers are the most commonly used class of breakers, in particular ammonium, potassium, and sodium salts of peroxydisulfate (persulfate) [68]. Enzymes may be used depending on fracturing conditions, particularly $\mathrm{pH}$ and temperature.

2.6. Acids and Bases. Acids and bases are added to HF fluids to adjust $\mathrm{pH}$, which improves the effectiveness of almost all HF compounds, particularly cross-linked polymers. The use of acids also clears debris in the wellbore and provides an open channel for other HF fluids by dissolving carbonate minerals [56]. Lastly, $\mathrm{pH}$ adjustment prevents unwanted microbial activity in the wellbore. 
Typical $\mathrm{pH}$ adjusters include inorganic acids such as hydrochloric and sulfuric acids, as well as organics such as acetic acid and fumaric acid. Common bases include potassium hydroxide, sodium hydroxide, sodium carbonate, and potassium carbonate [46].

2.7. Biocides. Biocides are used to control microbial growth in the boreholes and well areas, as such growths degrade HF chemicals and accelerate corrosion of well tubing, casings, and equipment [47, 70]. Biocides used for $\mathrm{HF}$ include quaternary ammonium compounds (QACs), glutaraldehyde, tetrakis hydroxymethyl phosphonium sulfate (THPS), tributyl tetradecyl phosphonium chloride (TTPC), and brominated compounds including 2,2-dibromo-3-nitrilopropionamide (DBNPA) [47, 56, 71]. QACs are extensively used as bioactive agents; the most commonly used ones are dialkonium and benzalkonium chlorides. Ammonium chloride is also used $[46,72]$.

2.8. Corrosion Inhibitors. Corrosion inhibitors form a protective layer on metal well components, thus preventing corrosion by acids, salts, and corrosive gases [73-75]. Common corrosion inhibitors include acetaldehyde, acetone, ethyl methyl derivatives, formic acid, and isopropanol $[46,76]$.

2.9. Scale Inhibitors. Scale inhibitors protect piping in the wells and prevent formation plugging. These inhibitors consist of polycarboxylates and acrylate polymers [46].

2.10. Iron Control Substances. Precipitates of ferric iron $\left(\mathrm{Fe}^{3+}\right)$ block paths within pipes and rock formations, which impact productivity $[77,78]$. Ferric iron also inadvertently acts as a cross-linker in HF fluids containing gelling agents, thereby altering fluid viscosity [77]. Iron precipitation is prevented using citric acid, acetic acid, thioglycolic acid, and sodium erythorbate [79]. Iron controlling agents act as chelating agents, forming complexes with ferrous iron $\left(\mathrm{Fe}^{2+}\right)$ to prevent oxidation and subsequent precipitation as $\mathrm{Fe}^{3+}[70,80]$.

2.11. Clay Stabilizers. In order to prevent clay swelling around shale formations, clay stabilizers are injected with HF fluids. These work via ion exchange, replacing cations such as $\mathrm{Na}^{+}$ in the clay with other, often divalent cations that undergo less hydration and have a lesser tendency to swell the clay [81]. Commonly used clay stabilizers are choline chloride, potassium chloride, and tetramethyl ammonium chloride [46]. There has been some shift towards choline chloride use, which is nontoxic and readily biodegradable.

2.12. Surfactants. Surfactants are used to achieve optimal viscosity of HF fluids, reduce surface tension, and assist in fluid recovery after fracturing $[5,46,70]$. Surfactants can be used in place of cross-linkers and gelling agents in high temperature or high pressure formations. Surfactant formulations used in HF vary greatly, but common compounds include sodium lauryl sulfate and dimethyl dehydrogenated tallow ammonium chloride $[46,76]$.
The large quantity and diversity of compounds used in $\mathrm{HF}$ additives underscore the complexity of understanding their fates in the event of release, whether accidental or managed, to soil. Furthermore, the compounds described for each agent are only the known compounds; hazards relating to proprietary compounds remain unknown.

\section{Flowback and Produced Water}

As oil and gas production proceed, formation water eventually reaches the production well, and water begins to appear alongside the hydrocarbons. This produced water is a mixture of injected water, formation water, HF chemicals, and hydrocarbons [82-85].

Produced water has a complex composition but its constituents can be broadly classified into organic and inorganic compounds. These include dissolved and dispersed oil components, grease, heavy metals, radionuclides, HF chemicals, dissolved formation minerals, salts, dissolved gases (including $\mathrm{CO}_{2}$ and $\mathrm{H}_{2} \mathrm{~S}$ ), scale products, waxes, microorganisms, and dissolved oxygen $[49,50,53,83,86,87]$. The composition will vary widely as a function of geologic formation, lifetime of the reservoir, and type of hydrocarbon produced [83].

A generalized chemical composition of produced water appears in Table 3.

3.1. Production Chemicals. Production chemicals, that is, HF fluids, enter produced water in traces and sometimes significant quantities [88] and vary from platform to platform. Active ingredients partition themselves into all phases present depending on their relative solubilities in oil, gas, or water.

3.2. Dissolved Minerals. Flowback water tends to have extremely high concentrations of total dissolved solids (TDS); this is due to dissolution of constituents from the formation following injection of HF fluids $[89,90]$. High salinity may also originate from release of in situ brines (formation water) [90-93]. Levels of TDS can be 5-10 times the concentration in seawater [90]. $\mathrm{Na}^{+}$and $\mathrm{Cl}^{-}$are responsible for salinity and range from a few $\mathrm{mg} / \mathrm{L}$ to $300,000 \mathrm{mg} / \mathrm{L}$ [94]. For comparison, seawater and salt lakes are defined as having an upper limit of 50,000 mg/L [95]. Ions such as $\mathrm{Cl}^{-}, \mathrm{SO}_{4}{ }^{2-}$, $\mathrm{CO}_{3}{ }^{2-}, \mathrm{HCO}_{3}{ }^{2-}, \mathrm{Na}^{+}, \mathrm{K}^{+}, \mathrm{Ca}^{2+}, \mathrm{Ba}^{2+}, \mathrm{Mg}^{2+}, \mathrm{Fe}^{2+}$, and $\mathrm{Sr}^{2+}$ affect conductivity and scale-forming potential. High levels of organic carbon also occur in substantial levels in flowback fluids and produced water $[89,96]$.

Fluid chemical composition is dependent, in part, upon its interaction time with the shale play. It has been found that TDS levels in produced water and late flowback can increase four-fold over that of early flowback. Similarly, total suspended solids (TSS) concentrations increase over 100 -fold between early and late flowback. Concentrations of inorganic ions in produced water from Marcellus shale (PA) wells increased over the course of oil production [89, 96-98], rising significantly during the initial days after fracturing and then increasing more slowly as the well aged $[76,89,96]$. 
TABLE 3: Composition of oilfield produced water.

\begin{tabular}{|c|c|c|c|}
\hline Parameter & Range & Metal & Range (mg/L) \\
\hline Density $\left(\mathrm{kg} / \mathrm{m}^{3}\right)$ & $1014-1140$ & $\mathrm{Ca}$ & $13-29,222$ \\
\hline Conductivity $(\mu \mathrm{S} / \mathrm{cm})$ & $4200-58,600$ & $\mathrm{Na}$ & $132-97,000$ \\
\hline Surface tension $(\mathrm{dyn} / \mathrm{cm})$ & $43-78$ & $\mathrm{~K}$ & $24-4,300$ \\
\hline Turbidity (NTU) & 182 & $\mathrm{Mg}$ & $8-6,000$ \\
\hline $\mathrm{pH}$ & $4.3-10$ & $\mathrm{Fe}$ & $<0.1-100$ \\
\hline TOC $(\mathrm{mg} / \mathrm{L})$ & $0-1,500$ & $\mathrm{Al}$ & $310-410$ \\
\hline TDS & 267,588 & B & $5-95$ \\
\hline TSS (mg/L) & $1.2-10,623$ & $\mathrm{Ba}$ & $1.3-650$ \\
\hline Dissolved oxygen (mg/L) & 8.2 & $\mathrm{Cd}$ & $<0.005$ \\
\hline Total oil (mg/L) & $2-565$ & $\mathrm{Cu}$ & $<0.02-1.5$ \\
\hline Volatiles (BTEX; mg/L) & $0.39-35$ & $\mathrm{Cr}$ & $0.02-1.1$ \\
\hline TPH (mg/L) & $>20$ & $\mathrm{Li}$ & $3-50$ \\
\hline Chloride (mg/L) & $80-200,000$ & Mn & $<0.004-175$ \\
\hline Bicarbonate (mg/L) & $77-3,990$ & $\mathrm{~Pb}$ & $0.002-8.8$ \\
\hline Sulfate (mg/L) & $<2-1,650$ & $\mathrm{Sr}$ & $0.02-2,204$ \\
\hline Sulfite $(\mathrm{mg} / \mathrm{L})$ & 10 & $\mathrm{Ti}$ & \\
\hline $\mathrm{NH}_{3}-\mathrm{N}(\mathrm{mg} / \mathrm{L})$ & $10-300$ & $\mathrm{Zn}$ & $<0.01-0.7$ \\
\hline Phenol (mg/L) & & As & $0.01-35$ \\
\hline \multirow[t]{5}{*}{ Volatile fatty acids (mg/L) } & $0.009-23$ & $\mathrm{Hg}$ & $<0.005-0.3$ \\
\hline & $2-4,900$ & $\mathrm{Ag}$ & $<0.005-0.3$ \\
\hline & & $\mathrm{Be}$ & $<0.001-0.15$ \\
\hline & & $\mathrm{Ni}$ & $<0.001-0.004$ \\
\hline & & & $<0.001-1.7$ \\
\hline
\end{tabular}

[49-51].

3.3. Metals. Oilfield produced water contains heavy metals such as mercury and lead, as well as metalloids such as arsenic, in varied concentrations depending on formation geology and age of the well $[49,99]$. Metal concentrations in produced water are usually higher than those found in sea water $[83,94]$. The most commonly studied metals are $\mathrm{Ba}, \mathrm{Cd}$, $\mathrm{Cr}, \mathrm{Cu}, \mathrm{Pb}, \mathrm{Hg}, \mathrm{Ni}, \mathrm{Ag}$, and $\mathrm{Zn}$ (Table 3) [50]. Produced water contains other trace metals including $\mathrm{Al}, \mathrm{B}, \mathrm{Fe}, \mathrm{Li}, \mathrm{Mn}, \mathrm{Se}$, and Sr. Certain metals are of particular environmental concern as they may bioaccumulate and/or be toxic [50].

3.4. Dissolved and Dispersed Oil Components. Dispersed and dissolved oil components are derived from the source rock and chemical additives in HF fluids, and their concentrations may be very high at some oilfields $[86,88,100,101]$. BTEX, phenols, aliphatic hydrocarbons, carboxylic acid, and low molecular weight aromatics are classified as dissolved oil, while the more hydrophobic PAHs and heavy alkyl phenols are present in produced water as dispersed oil [100].

Produced water from the Marcellus (PA) and Barnett (TX) plays contains predominantly $\mathrm{C}_{6}-\mathrm{C}_{16}$ hydrocarbons, while Eagle Ford (TX) produced water shows the highest concentration in the $\mathrm{C}_{17}-\mathrm{C}_{30}$ range [102]. The structures of saturated hydrocarbons identified generally follow the trend of linear $>$ branched $>$ cyclic. Heterocyclic compounds, fatty alcohols, esters, and ethers have also been identified. The presence of various fatty acid phthalate esters in the Barnett and Marcellus produced water may be related to their use in
HF fluids [102]. No polyaromatic hydrocarbons (PAHs) were observed in these shale plays [102].

3.5. Produced Solids. Produced solids include clays, precipitated solids, waxes, microbial biomass, carbonates, sand and silt, corrosion and scale products, proppant, formation solids, and other suspended solids [49]. Their concentrations vary from one oilfield to another.

\section{OGPW in the Terrestrial Environment: Releases, Effects, and Remediation}

4.1. Releases. The management of OGPW is largely monitored and controlled; however, accidental releases are inevitable. In addition, application of HF fluids to soil is considered an acceptable form of disposal in many states [103]. Inadvertent releases and intentional land application could potentially expose soil to hundreds of heterogeneous chemicals. The US EPA has studied potential scenarios that could lead to environmental contamination by HF fluids [104].

4.1.1. Pipe Overflows, Leaks, and Blowouts. In a 2009 study it was revealed that 630 out of 4,000 legally permitted wells in Pennsylvania had drilling site leaks [105]. In 2011 a mechanical problem at a Pennsylvania natural gas well caused thousands of gallons of briny water and HF fluid to erupt from the well, overwhelm containment facilities, and flow into surrounding fields. Local families were ordered to evacuate their homes. After six days workers sealed the leak, replaced the wellhead, and got the well "under control" [3].

In 2014 a North Dakota oil well leaked HF fluid and oil, releasing between 2,100 and 2,940 gallons per day of OGPW and 8,400 gallons per day of oil [106]. In a 2015 North Dakota well blowout, 4,620 gallons of OGPW and 23,100 gallons of oil were released. Most of the spill was contained at the well site, but some escaped and contaminated nearby terrain [107]. From January 2006 to October 2014 more than 18 million gallons of OGPW and oil was spilled in North Dakota alone. Most individual spills were contained to the immediate drilling area, but many larger spills affected surrounding farms and waterways [36].

4.1.2. Deliberate Improper Disposal. A petroleum subsidiary had permission to discharge drilling mud and boring waste to an oilfield sump near almond orchards in Shafter, California. State investigators, however, found that the fluid contained excess salinity, boron, benzene, and gasoline and diesel hydrocarbons believed to have been used in $\operatorname{HF}[19,108]$.

4.1.3. Holding Ponds. Gas and oil producers are increasingly reusing spent HF fluids. However, reuse involves storage in holding ponds and eventually diluting the OGPW with fresh water [109]. In 2009 a wastewater pit overflowed at a Pennsylvania gas well and an unknown quantity of OGPW entered a "high quality watershed." The company failed to report the spill and in 2010 a fine of $\$ 97,350$ was levied against the company [3]. 
4.1.4. Natural Events. Natural disasters such as floods add to the potential for soil contamination by OGPW. During the late 2013 floods in Colorado, floodwaters in Weld County (where 20,000 oil and gas wells are located) surged into drilling centers and damaged pipes, overflowed wells, and shifted oil tanks from their foundations [110]. Approximately 35,000 gallons of oil and condensate were released. HF fluids from evaporation pits may have contaminated local soils and possibly been carried farther by the floodwaters [19].

4.2. Effects on the Soil Resource. Potential soil quality and plant impacts from OGPW include the following [100]:

(i) Excess sodicity can cause clays to deflocculate, thereby lowering the permeability of soil to air and water.

(ii) Excess soluble salts will cause plants to desiccate and die. Where levels of natural precipitation are low, salts may accumulate to excessive concentrations in soil.

(iii) Existing plant species may become displaced by new species as a result of chemical changes in soils resulting from contact with OGPW.

(iv) Salt-tolerant plants may increase in distribution.

In a greenhouse study Swiss chard (Beta vulgaris L.) and ryegrass (Lolium perenne L.) were grown in soils containing synthetic HF fluids [111]. The HF fluids increased soil pH, EC, and concentrations of total and extractable $\mathrm{Zn}, \mathrm{Cu}, \mathrm{Cd}, \mathrm{Pb}$, and As. Chard and ryegrass yields may have been reduced by high soil $\mathrm{Zn}$ and EC levels. The HF fluids may have resulted in lower levels of trace elements in plant tissue due to increased soil $\mathrm{pH}$. In a greenhouse study Miller et al. [112] studied the effects of OGPW components on plant growth and found that diesel oil, $\mathrm{KCl}, \mathrm{NaOH}, \mathrm{Cr}$, starches, and other compounds reduced yields of sweet corn (Zea mays L. var. saccharata) and/or green beans (Phaseolus vulgaris L.).

Six drilling fluids reduced yields of green beans and sweet corn when added to soils at differing ratios [113]. High levels of soluble salts or high percentage exchangeable $\mathrm{Na}^{+}$was considered to be the major cause of reduced plant growth. Adams [103] reported severe acute and chronic toxicity of mixed hardwood trees (Quercus spp., Acer rubrum L., and Liriodendron tulipifera), mixed shrub subcanopy (Fagus grandifolia (Ehrh.), A. rubrum, and Sassafras albidum (Nutt.)), and ground vegetation (Vaccinium L., Smilax rotundifolia L., and Kalmia latifolia L.) that resulted in 56\% vegetation mortality after two years of land application of HF fluid. Soil $\mathrm{Na}^{+}$and $\mathrm{Cl}^{-}$concentrations increased by approximately $50-$ fold as a result of land application of the fluids.

OGPW components in soil may substantially impact each other's fate and transport; for instance, the presence of biocides may decrease the potential for biodegradation, while viscosity-enhancing compounds may hinder the mobility of other compounds. Factors that affect the behavior of OGPW constituents in soil and therefore their potential impact on terrestrial life include the following [100]:

(i) Dilution of the OGPW in the receiving environment. (ii) Immediate and long-term precipitation of metals and other contaminants.

(iii) Volatilization of low molecular weight hydrocarbons.

(iv) Physical-chemical reactions with other chemical species present in soil.

(v) Adsorption to particulate matter.

(vi) Biodegradation of organic constituents.

Some specific HF components and their possible fates are described below.

4.2.1. Gelling Agents. Gellants such as guar and cellulose occur naturally and are nontoxic and readily biodegradable. The same is true for the common acids and alcohols used as gelling agents [46]. It is likely that these compounds, when in contact with soil, will enhance microbiological growth.

Ethylene glycol is highly soluble in water; it adsorbs poorly to soil colloids and is thus highly mobile in the soil profile [114]. Volatilization of ethylene glycol from soil is not expected.

4.2.2. Friction Reducers. Polyacrylamide is readily biodegradable. McLaughlin [115] studied transformation kinetics of PAM and polyethylene glycol (PEG) in the presence of cocontaminants. Over time higher rates of disappearance occurred in raw, that is, biologically active, soil compared with sterilized soil, indicating that PEG disappearance is due to both sorption and biodegradation. In a study by Wen et al. [116], two PAM-degrading bacterial strains were isolated from soil in an oilfield contaminated by PAM; these were identified as Bacillus cereus and Bacillus flexus. No acrylamide, which is a known human carcinogen, mutagen, and teratogen, was produced during aerobic biodegradation of polyacrylamide [116, 117]; however, it has been suggested that acrylamide may be formed via heating or exposure of polyacrylamide to ultraviolet radiation $[116,118]$.

4.2.3. Cross-Linkers. Human exposure to boron and amines used in cross-linkers is of concern as they have known toxic effects and can be mobile in soil and groundwater; however, the amines are not known to persist in the environment [46].

4.2.4. Breakers. The use of enzymes as breakers for fracturing fluids is preferred over the use of oxidizers because enzymes are environmentally benign [68]. Their mobility, however, remains largely unknown [76].

4.2.5. Acids and Bases. Organic acids are potentially biodegradable depending on concentration. Strong acids or bases are known to cause adverse effects on soil. For example, strong acidity will result in leaching of bases such as $\mathrm{Ca}^{2+}$ and $\mathrm{Mg}^{2+}$ [119]; extremes of acidity will cause dissolution of soil solids [120]. The hydrated $\mathrm{Na}^{+}$ion in sodium hydroxide disperses soil aggregates and destroys soil structure. Extremes in $\mathrm{pH}$ may drastically alter microbial composition [121]. 
4.2.6. Biocides. Some common HF biocides are known to be volatile or sorb to soils and can persist in the environment, although their fates are largely unknown [76].

QACs have distinct physical/chemical properties which are conferred by their substituents, primarily alkyl chain length. The mechanism of QAC sorption to solids is complex, but both hydrophobic and ionic interactions probably occur [122]. The $\log K_{\mathrm{OC}}$ values of several mono-, di-, and benzalkonium chlorides range between 0.28 and 2.97 [123, 124]. QACs are therefore expected to sorb to soil colloids and not leach to groundwater. Sorption of QACs on organic surfaces such as humic compounds and sediment increases as the alkyl chain length increases [122]. In the benzalkonium chlorides the benzyl group enhances adsorption.

QACs have been identified in sediments near wastewater discharge sites, suggesting that at least some are environmentally persistent $[125,126]$. The degree of biodegradability is variable; biodegradation decreases with increasing length of the alkyl chain, and QACs that contain a benzyl group experience lower biodegradation rates [127]. QACs were found to be recalcitrant under methanogenic conditions [122]. Under nitrate reducing and fermentative conditions, benzalkonium chlorides (BACs) were transformed to alkyldimethyl amines via abiotic reactions [122]. Microorganisms have been isolated that are resistant to QACs and capable of QAC degradation [128-132]. In a study by Tezel [122] the bacterial community involved in aerobic degradation of BACs was mainly composed of species belonging to the genus Pseudomonas.

Generally, QAC sorption exceeds biodegradation in aerobic biological systems [46, 125, 129].

Glutaraldehyde (GA) and the phosphonium-based biocides are sometimes considered "green" alternatives to conventional biocides as they are less persistent in the environment. GA is readily biodegradable under both aerobic and anaerobic conditions $[133,134]$. In aerobic batch experiments McLaughlin [115] studied decomposition of GA and didecyl dimethyl ammonium chloride (DDAC) to determine transformation kinetics in the presence of cocontaminants. DDAC underwent almost immediate sorption to soil. GA slowed the initial rate of PEG and PAM biodegradation. After one week, GA was completely eliminated from the aqueous phase due to sorption.

DDAC-degrading bacteria were isolated via enrichment culture with DDAC as the sole carbon source [130]. One isolate, Pseudomonas fluorescens TN4, degraded DDAC to produce decyldimethylamine and subsequently dimethylamine as intermediates. The TN4 strain also assimilated other QACs, alkyltrimethyl- and alkyl benzyl dimethyl ammonium salts, but not alkylpyridinium salts. TN4 was highly resistant to these QACs and degraded them by an N-dealkylation process [130].

Tetrakis hydroxymethyl phosphonium sulfate (THPS) has low $K_{\mathrm{OW}}(140)$ [135], $K_{\mathrm{OC}}$, and $K_{\mathrm{H}}$ values, which suggests it will not sorb to soil but will leach to groundwater. Under abiotic conditions THPS is readily biodegradable [46]. THPS decomposes under natural conditions via hydrolysis, oxidation, and photodegradation [104]; it initially degrades to trihydroxymethyl phosphine (THP), releasing formaldehyde and sulfuric acid [136]. Carbon dioxide, water, and inorganic phosphate are among the final products [137]. At $\mathrm{pH} 5-7$ the half-lives of THPS exceed 30 days; at $\mathrm{pH}>8$ THPS degrades within 7 days. THPS is expected to volatilize from dry soil surfaces [138].

DBNPA has low $\log K_{\mathrm{OW}}$ and $K_{\mathrm{OC}}$, suggesting it will not sorb to soil and may leach to groundwater. Disappearance of DBNPA in soil may be due to hydrolysis, adsorption, chemical degradation, and/or microbial degradation. Sunlight also degrades DBNPA [139]. Hydrolysis reactions convert DBNPA into dibromoacetonitrile, followed by dibromoacetamide, dibromoacetic acid, glyoxylic acid, and oxalic acid. The most stable product of these products is dibromoacetic acid.

4.2.7. Corrosion Inhibitors. In general, corrosion inhibitors are highly soluble and biodegradable. Their low $\log K_{\mathrm{OW}}$ and $K_{\mathrm{OC}}$ values indicate that these chemicals are not likely to sorb to soils, and there is potential for leaching to groundwater. This group contains compounds that are toxic and/or carcinogenic $[46,76]$.

Propargyl alcohol and thiourea are GHS Category 2 chemicals, making them among the most toxic chemicals used in HF fluids. Propargyl alcohol is considered readily biodegradable; it is also highly mobile in soil [140]. Volatilization of propargyl alcohol from moist soil surfaces is expected to be substantial, given an estimated Henry's Law constant of $1.1 \times 10^{-6}$ atm-cu m/mole [140]. Volatilization from dry soils is also expected to occur. The half-life of propargyl alcohol in an alkaline silt loam soil $(\mathrm{pH} 7.8,3.25 \%$ organic carbon) was 12.6 days and 13 days in an acidic sandy loam ( $\mathrm{pH} 4.8,0.94 \%$ organic carbon) $[140,141]$. Thiourea is considered biodegradable and highly mobile in soil. Sorption of thiourea to organic matter of three different soil orders was characterized as low (spodosol) to moderate (entisol/alfisol) [142].

4.2.8. Iron Control Agents. Acetic acid, citric acid, sodium erythorbate, and mercaptoacetic acid (thioglycolic acid) are highly soluble in water. The low $K_{\mathrm{OC}}$ values of citric acid and thioglycolic acid indicate that they will not sorb markedly to soils but will be mobile in the profile. The $\mathrm{p} K_{a}$ of thioglycolic acid is 3.55, suggesting that it will exist almost entirely in the anionic form in soil and will therefore not sorb to clay and organic matter [46]. With the exception of acetic acid, these compounds are not expected to volatilize from OGPW based on their Henry's Law constants [46].

All iron control agents, in particular acetic acid, citric acid, and thioglycolic acid, tend to be readily degraded and are not persistent $[143,144]$; however, some are known to be toxic [76]. Acetic acid, citric acid, and sodium erythorbate are of low toxicity to humans. Of the iron control agents, thioglycolic acid appears to be the greatest concern as a soil contaminant as it poses a toxicity risk based on an oral $\mathrm{LD}_{50}$ value of $114 \mathrm{mg} \mathrm{kg}^{-1}$ [145].

4.2.9. Surfactants. Most surfactants are highly soluble in water and readily biodegradable. Sodium lauryl sulfate has a moderately high $K_{\mathrm{OC}}$ value and is expected to have moderate to low mobility in soil $[46,76,146,147]$. Sodium lauryl sulfate 
occurs in household products and is not anticipated to be a health risk due to its $\mathrm{LD}_{50}$ value.

4.2.10. Excess Salinity. Soil salinity imposes ion toxicity, nutrient $(\mathrm{N}, \mathrm{Ca}, \mathrm{K}, \mathrm{P}, \mathrm{Fe}$, and $\mathrm{Zn})$ deficiencies, nutritional imbalances, osmotic stress, and oxidative stress on plants $[148,149]$. Soil salinity significantly reduces plant phosphorus (P) uptake because phosphate ions precipitate with Ca ions [150]. Some elements, such as $\mathrm{Na}, \mathrm{Cl}$, and $\mathrm{B}$, impart specific toxic effects on plants. Excessive accumulation of $\mathrm{Na}$ in cell walls can lead to osmotic stress and cell death [151]. All these factors cause adverse effects on plant growth and development at physiological and biochemical levels [152] and at the molecular level [153]. Salinity hinders seed germination; seedling growth; enzyme activity; DNA, RNA, and protein synthesis; and mitosis $[154,155]$.

4.2.11. Hydrocarbons. The primary hydrocarbons which contribute to acute toxicity of OGPW are the aromatic and phenol fractions of dissolved hydrocarbons [156].

4.3. Soil Remediation. In situ remediation of HF-affected soil involves (1) removal of salts in the soil solution via leaching with irrigation or natural precipitation; (2) replacement of exchangeable $\mathrm{Na}^{+}$with $\mathrm{Ca}^{2+}$; (3) removal or destruction of hydrocarbons; and (4) removal or immobilization of metals. Remediation practices on OGPW-contaminated soils often tend to be straightforward.

4.3.1. Treatment of Salinity and Sodicity. Simple soil dilution may relieve salinity problems following release of OGPW. In the study by Wolf et al. [157], OGPW occurred primarily at the soil surface. Mixing of the less-contaminated deeper soil with the surface soil resulted in dilution of contaminants. Ahmad et al. [158] and Lloyd [159] concluded that the salt concentration of drilling waste was the primary factor in determining the waste loading rate in soil systems.

Addition of inexpensive amendments is often successful in treating soil salinity and sodicity problems. Both inorganic amendments (e.g., $\mathrm{CaSO}_{4}[160]$ ) and organic materials (animal manures) have proven to be successful. The most commonly used dry amendments are gypsum $\left(\mathrm{CaSO}_{4} \cdot 2 \mathrm{H}_{2} \mathrm{O}\right)$ and calcium nitrate $\left(\mathrm{Ca}\left(\mathrm{NO}_{3}\right)_{2}\right)$, although calcium chloride $\left(\mathrm{CaCl}_{2}\right)$ may be used if adequate drainage control is provided and leachate is managed [37]. Use of calcium amendments may require subsequent irrigation and leachate collection to move the calcium amendment into the affected soil layers for replacement of $\mathrm{Na}$ and to leach salts beyond the root zone. Sulfur may be applied, either as elemental S or as aluminum sulfate, to decrease $\mathrm{pH}$.

Livestock manure can be successfully used as a soil amendment. Organic material creates macropores thus allowing for soil drainage; it furthermore greatly augments soil biological activity. Only well-decomposed or composted manure should be used in order to limit inputs of salts and to prevent proliferation of weeds. Addition of significant organic amendments such as chicken or some feedlot manures can increase soil salinity over several applications. Testing manure and compost for salinity is recommended [37, 161].
Organic amendments must be thoroughly mixed into soil upon application. Low-N organic matter such as cereal straw requires additional $\mathrm{N}$ for decomposition; therefore, a high- $\mathrm{N}$ fertilizer such as ammonium nitrate, ammonium sulfate, or calcium nitrate should be included [37].

Additional amendments may prove to be beneficial in treating OGPW-affected soil. For example, use of synthetic polymers (e.g., polyacrylamides) to stabilize aggregates has proved to be successful in improving the physical properties of Na-enriched soil [37, 162]. Given that soil biological activity may be drastically reduced in OGPW-contaminated soil, it is recommended that mycorrhizal fungi be applied [163].

Electrokinetic remediation has been suggested for treatment of saline soils [160]. This technology involves application of low density direct current between electrodes placed in the soil to mobilize contaminants which occur as charged species. This allows for separation and removal of $\mathrm{Na}^{+}, \mathrm{Cl}^{-}$, and other highly soluble ions. Electrodes can be installed horizontally or vertically in deep, directionally drilled tunnels or in trenches around sites contaminated by OGPW [164].

When the average EC of the uppermost soil is > $35,000 \mathrm{uS} / \mathrm{cm}$, soil removal and replacement may be more economical than treatment [160]. It may be costly, however, to haul and dispose contaminated soil at a special waste landfill. There is also potential long-term liability of impacted soil placed in a landfill [165].

4.3.2. Treatment of Hydrocarbon Contamination. Hydrocarbon contamination of OGPW-affected soils is typically not expected to be significant, given the relatively low concentrations occurring in OGPW. However, in cases of a catastrophic release, microbial decomposition of oily wastes is encouraged. So-called bioremediation processes, if conducted properly, should result in few residuals and minimal alteration of the local environment [164].

In situ bioremediation systems introduce aerated, nutrient-enriched water into the contaminated zone through an array of injection wells, sprinklers, or trenches. Sufficient time is allowed for the reaction of indigenous microbial communities with the contaminants, and the treated water is eventually recovered downgradient. The recovered water may be further treated (e.g., passage over granular activated carbon) and reintroduced to the affected soil. Otherwise it may be discharged to a municipal wastewater treatment plant or to surface water $[164,166]$.

The affected soil should receive adequate nutrients (in particular, $\mathrm{N}$ and $\mathrm{P}$ ) to promote microbial growth and activity. Also, it is essential that adequate oxygen be available, which may be provided by aeration of the flushing solution. Soil $\mathrm{pH}$ must be maintained near neutral in order to promote microbial proliferation [164].

In slurry biodegradation, contaminated soil is transferred from the affected area to a lined lagoon and mixed with water. The slurry is continuously stirred and aerated in the lagoon. Decomposition of organic contaminants takes place via aerobic microbial processes. Slurry biodegradation can treat a range of hydrocarbons including crude and refined petroleum products [167-169]. The presence of heavy metals 
and other potential toxins in OGPW (e.g., biocides) may inhibit microbial metabolism and require pretreatment.

A significant benefit in the use of slurry biodegradation is the enhanced rate of contaminant degradation, a direct result of improved contact between the microorganisms and hydrocarbons. The agitation of contaminants in the liquid phase provides for a high degree of solubilization of compounds and significant homogeneity [167].

Land treatment techniques for bioremediation, for example, landfarming, are commonly used for treatment of hydrocarbon-contaminated soil [170]. Contaminants treated include fuel, lubricating oil, and pesticides. Landfarming can be regarded as a combination of biodegradation and soil venting; microbial oxidation reactions occur in combination with volatilization.

A common field installation calls for the affected soil to be excavated and transferred to a prepared location (a land treatment unit or cell) which is designed for controlling the process. Treatment involves installation of layers ("lifts") of contaminated soil to the cell. The cell is usually graded at the base to provide for drainage and lined with clay and/or plastic to contain all runoff within the unit. It may also be provided with sprinklers or irrigation and drainage. Because of the high water application rates, LTUs are often bordered by berms [164].

A major benefit of the land treatment technique is that it allows for very close monitoring of process variables that control the decomposition of hydrocarbons $[164,170]$.

4.3.3. Treatment of Metals Contamination. Metals at OGPWcontaminated sites may occur in complex forms.

Metals may be extracted from soil via elutriation for eventual recovery, treatment, and disposal. Also known as soil flushing, contaminants are solubilized or similarly desorbed from solid forms and recovered [171]. Metal removal efficiencies during soil flushing depend not only on soil characteristics but also on metal concentration, chemistry of the metal(s), extractant chemistry, and overall processing conditions [171].

In situ extraction processes are applicable for either the vadose zone or the saturated zone. The flushing solution is applied to the affected site via sprinklers or irrigation, or by subsurface injection. A sufficient period is allowed for the applied reagents to percolate downward and react with contaminant metals. The contaminants are subsequently mobilized by solubilization. The elutriate is collected in strategically placed wells [164]. Metals which are minimally soluble in water often require acids, chelating agents, or other solvents for successful washing [172].

One drawback to soil flushing technology is the possible production of residuals. These include excess chelating agents, some of which may be toxic to biota. In addition, leaching of soil with dilute acids may destroy the biological portion of the soil, alter its chemical and physical properties, and create a relatively inert material [164].

Phytoremediation is a cost-effective, low-technology process defined as the engineered use of green plants to extract, accumulate, and/or detoxify environmental contaminants. Phytoremediation employs common plants including trees, vegetable crops, grasses, and even annual weeds to treat heavy metals in soil [173-175].

A simple and common application of phytoremediation is phytoextraction, which involves the use of hyperaccumulating plants to take up metals from the soil and concentrate them into roots and aboveground shoots. In certain cases contaminants can be concentrated thousands of times higher in the plant than in the soil. Following harvest of the extracting crop, the metal-rich plant biomass can be ashed to reduce its volume, and the residue can be processed as an "ore" to recover the contaminant metals. If recycling the metal is not economically feasible, the small amount of ash (compared to the original plant biomass or the large volume of contaminated soil) can be disposed [164, 173-176].

Phytoremediation is useful for soils contaminated with metals to shallow depths. This technology can work well in low permeability soils, where many technologies have a low success rate. It can also be used in combination with conventional cleanup technologies (e.g., "pump and treat" of groundwater). Phytoremediation can be an alternative to harsher remediation technologies such as soil flushing [164].

\section{Pollution Prevention for OGPW}

Once OGPW has been brought to the surface it is either disposed or reused. Given that OGPW is enriched in TDS, TSS, metals, dispersed oil, dissolved and volatile organic compounds, $\mathrm{HF}$ additives, and other contaminants to varying degrees (Table 3), significant management challenges face operators. OGPW must be managed in ways that both reduce the operational costs as well as are protective of the environment. OGPW management practices vary widely across the United States and in some instances across a single oil and gas field [177].

OGPW management falls under two broad categories: underground injection and surface management. Selection of a management option for OGPW at a site varies based on the following [178]:

(i) Chemical and physical properties of the OGPW.

(ii) Volumes, duration, and flow rate generated.

(iii) Desired end-use of the wastewater.

(iv) Treatment and disposal options allowed by state and federal regulations.

(v) Technical and economic feasibility of a particular option, including transportation.

(vi) Availability of suitable infrastructure for management.

(vii) Willingness of companies to employ a particular technology or management option, including concerns about potential liability.

Some common options available to oil and gas operators for managing OGPW are addressed below.

5.1. Limit Production of Water at the Surface. Technologies are available for managing water within the wellbore. These 
technologies do not reduce the volume of water entering the well but minimize the quantity of OGPW that rises to the surface.

5.1.1. Downhole Oil/Water Separation and Injection. Downhole oil/water separators (DHOWS) separate water from oil within the wellbore so that oil or gas with little water is brought to the surface. Significant quantities of water are disposed in nonproducing formations above or below the oil- or gas-producing formation using injection tools within the well [100]. The downhole separator assembly comprises several compact elements installed within the wellbore including (1) a separation tool, which separates OGPW from incoming hydrocarbons from the formation; (2) a pump that pressurizes water from the separator and injects the OGPW into the disposal zone; (3) a heavy-duty motor to perform the pumping; and (4) miscellaneous equipment such as downhole monitoring equipment and cables [177].

5.1.2. Downhole Gas/Water Separators. Devices similar to DHOWS are available for gas wells. A study by the Gas Research Institute identified 53 commercial field tests of downhole gas/water separators involving 34 operators in the USA and Canada [179]. Gas production rates increased in $57 \%$ of the tests; $47 \%$ of the field tests were considered successful [100].

5.1.3. Dual Completion Wells. Oil production may decline in a well as water generates a "cone" around the production perforations, limiting the volume of oil that can be recovered. This phenomenon may be reversed and managed by completing the well with two separate tubing strings and pumps. The primary completion is made at a depth corresponding to strong oil production, and a secondary completion is made lower in the strata at a depth experiencing significant water production. The two completions are separated by a packer. The oil collected above the packer is brought to the surface, and the water collected below the packer is injected into a lower formation [100, 180, 181]. Swisher [182] reports on the results of using a dual completion well compared to three wells with conventional completions in a Louisiana oilfield. The dual completion well costs about twice as much to install but took the same number of months to reach payout as the other wells. However, at payout, it was producing $55 \mathrm{bpd}$ of oil compared to about $16 \mathrm{bpd}$ from the other three wells. Wojtanowicz [183] provides additional examples of using dual completion wells from differing geological settings.

5.2. Injection of $O G P W$. Injection involves the emplacement of OGPW into porous geologic strata by pumping, via an injection well, into a formation capable of receiving and storing water. Injection wells are regulated by the Federal Underground Injection Control (UIC) program which was initiated under the Safe Drinking Water Act to prevent contamination of underground sources of drinking water (USDW).

Approximately 90\% of OGPW from land-based oil and gas recovery operations in the United States is reinjected into underground formations. Hundreds of thousands of injection wells operate daily to manage produced water and flowback [178, 184]. OGPW may be injected back to its formation or into other suitable formations [185]. Injection is dependent upon several variables including the availability of receiving formation(s); the quality of OGPW being injected; the quality of water in the receiving formation; and the ultimate storage capacity of the receiving formation(s). These factors will influence what type of injection well can be used for managing OGPW.

Many papers have described the process of underground injection of wastewater. Only a brief review is provided here.

The US EPA classifies five different injection well categories (Table 4); three may be applicable for management of produced water. In general, OGPW is considered an exempt waste and therefore can be injected in Class II or Class V injection wells. Class II wells may be used to hold fluids associated with oil and natural gas production [52] and are classified either as disposal wells (IID) or as enhanced recovery wells (IIR). Wastewater resulting from OGPW treatment must be disposed in Class I injection wells. EPA defines Class I wells as technologically sophisticated wells that inject hazardous and nonhazardous wastes below the lowermost USDW. Injection occurs into deep, isolated rock formations that are separated from the lowermost USDW by layers of impermeable clay and rock [52]. Class V wells (i.e., shallow injection, subsurface drip irrigation) are injection wells not included in the other four classes. Their simple construction provides little protection against possible soil and groundwater contamination.

Underground injection of OGPW often requires transport, along with treatment to reduce fouling and bacterial growth. Storage over the long-term may be required.

5.3. Beneficial Use: Discharge OGPW to the Surface. Some important emerging opportunities for management of OGPW are (1) treatment and reuse as a water supply for public consumption, agriculture, and industry and (2) secondary industrial processes such as extraction of minerals [178]. The presence of certain constituents, however, may limit produced water use in selected areas [178]. Produced water may be discharged to the land as long as it meets both onshore and offshore discharge regulations [83].

OGPW may be discharged to the land surface to surface impoundments, for land application for crop use and industrial uses (i.e., oil and gas completion activities, truck wash station, dust suppression, and cooling tower water) [177]. A surface impoundment is defined as an excavation or diked area used for treatment, storage, or disposal of liquids [186]. Impoundments are usually constructed in low permeability soils. These vary in size from $<1$ acres to several hundred acres. Based on an EPA national survey that characterized 180,000 impoundments, the oil and gas industry uses impoundments for storage (29\%), disposal (67\%), and treatment (4\%) [186].

Impoundments are used for OGPW management including evaporation and/or infiltration; storage prior to injection or irrigation; or beneficial use such as livestock and wildlife watering ponds, constructed wetlands, fishponds, or a recreational pond. 
TABLE 4: US EPA injection well classification system.

\begin{tabular}{|c|c|c|}
\hline Well class & Injection well description & Approximate inventory \\
\hline \multirow{3}{*}{ Class I } & Inject hazardous wastes beneath the lowermost USDW & \multirow{3}{*}{500} \\
\hline & Inject industrial nonhazardous liquid beneath the lowermost USDW & \\
\hline & Inject municipal wastewater beneath the lowermost USDW & \\
\hline \multirow{3}{*}{ Class II } & Dispose of fluids associated with the production of oil and natural gas & \multirow{3}{*}{147,000} \\
\hline & Inject fluids for enhanced oil recovery & \\
\hline & Inject liquid hydrocarbons for storage & \\
\hline Class III & Inject fluids for the extraction of minerals & 17,000 \\
\hline \multirow[b]{2}{*}{ Class IV } & Inject hazardous or radioactive waste into or above USDW, 40 sites & \\
\hline & $\begin{array}{l}\text { This activity is banned. These wells can only inject as part of } \\
\text { an authorized cleanup }\end{array}$ & \\
\hline Class V & Wells not included in the other classes. Inject nonhazardous liquid into or above a USDW & 500,000 to $>685,000$ \\
\hline
\end{tabular}

5.3.1. Evaporation Ponds. An evaporation pond is a large body of water that is designed to evaporate water by solar energy [187]. Such ponds are constructed to prevent subsurface infiltration [188]. Ponds are a favorable technology in regions where annual rainfall is relatively low and evaporation rates are high. If the pond is constructed solely for evaporative loss, it is typically designed as a broad shallow pool that takes advantage of the large surface area. Areas with high winds and few natural windbreaks provide additional evaporative potential and may be considered in siting a pond. Ponds are usually covered with netting to prevent problems to migratory waterfowl caused by contaminants in OGPW [189].

As pure water evaporates from the pond, TDS increase in the remaining water. Over time the remaining water may become concentrated brine [177].

Over 80 million gallons of OGPW are managed daily by EPA under the Clean Water Act's National Pollutant Discharge Elimination System (NPDES) for beneficial reuses such as agricultural irrigation $[100,184]$. The following is a summary of beneficial OGPW use practices in the USA.

5.3.2. Irrigation and Land Application. In the United States crop irrigation is the largest single use of freshwater, comprising $40 \%$ of all freshwater withdrawn, or 137 million gallons per day [190].

The determination of whether OGPW water can be used for agricultural purposes (i.e., irrigation, land application, and stock watering) depends both on the quality of the produced water and on characteristics of the recipient site. Relevant water and site variables include quantity of water required; length of time the water has been stored in impoundments prior to use; soil mineralogy, texture, and structure; and sensitivity of plant species [188].

The three most critical parameters regarding crop irrigation water quality requirements are salinity, sodicity, and elemental toxicity $[100,188]$. As salinity rises above a speciesspecific salinity threshold, crop yields decrease. Irrigation water high in TDS diminishes the ability of roots to incorporate water, and reduces crop yield. The tolerance of various crops to salinity has been documented [191]. EC levels > $3,000 \mu \mathrm{S} / \mathrm{cm}$ are considered saline.

Excess sodium can damage soil physical properties. Irrigation water with SAR $>12$ is considered sodic [100, 188]. Higher SAR values lead to soil dispersion and loss of structure and infiltration capability [119].

Under the Clean Water Act's Subpart E of 40 CFR Part 435, the NPDES permit system allows for the specialized reuse of wastewater from oil and gas facilities west of the 98th meridian. To qualify, the wastewater must contain < $35 \mathrm{mg} / \mathrm{L}$ of oil and grease and be used either for agriculture or for livestock watering [100]. The combination of the NPDES permitting allowance, the substantial requirement of water needed to perform $\mathrm{HF}$, and the frequent geographical overlap between extraction sites and agricultural land has led to reuse of OGPW for irrigation in some states [100].

Raw water either is discharged directly to the land surface or is pretreated with amendments prior to application. Amendments are site-specific depending on soil properties, water chemistry, and plant species grown. Amendments could also be added to soil prior to, or following, application. Wolf et al. [157] found that addition of inorganic fertilizer, broiler litter, and Milorganite ${ }^{\circledR}$ to OGPW-treated soil markedly improved growth of Bermuda grass [Cynodon dactylon (L.) Pers.].

A program was created at Texas A\&M University to develop a portable produced water treatment system that can be transported to oilfields to convert OGPW into irrigation or potable water. The goal was to produce water to levels of $<500 \mathrm{mg} / \mathrm{L}$ TDS and $<0.05 \mathrm{mg} / \mathrm{L}$ hydrocarbons [100, 192, 193]. Chevron Texaco developed a system to treat OGPW in Southern California [194]; 21 million gallons of oilfield water is recycled daily and sold to farmers who use it on about 45,000 acres of crops, about $10 \%$ of Kern County's farmland. The treated water is used for irrigation of fruit trees and other crops and for recharging shallow aquifers. An additional $360,000 \mathrm{bpd}$ of water is further purified and used to make steam at a cogeneration facility. State and local officials praise the two-decade-old program as a national model for coping with the region's water shortages [195]. 
Thousands of acres in the Powder River Basin (WY) have been transformed to productive agricultural land using produced water $[1,196]$. Livestock forage was irrigated using either OGPW on research plots or a blend of surface water and OGPW. Both treatments resulted in adequate crop production; however, the OGPW had to be applied at higher rates as plants did not utilize it as efficiently as the surface water blend [197]. Between watering intervals $\mathrm{CaSO}_{4}$ and other supplements were applied to offset high SAR. After two years the rangeland was converted into highly productive grassland yielding livestock and wildlife benefits [100, 198].

The use of subsurface drip irrigation of OGPW is gaining popularity [199]. BeneTerra LLC has developed subsurface drip irrigation technology to provide produced water for crops [200]. Produced water is filtered, treated, and pumped through polyethylene tubing which spreads it uniformly through soil. The tubing is installed with a chisel plow to depths ranging from 18 to 48 inches. Haying operations can continue while the field is being irrigated. The drip irrigation systems are designed to utilize the native $\mathrm{Ca}$ and $\mathrm{Mg}$ present in the soil to offset the effects of $\mathrm{Na}$. The salts percolate to a lower depth [1].

In some cases produced water may be treated for domestic supplies and drinking water. However, produced water from coal seams $>200$-feet depth often has water that exceeds salinity levels appropriate for domestic use (i.e., about $3,000 \mathrm{mg} / \mathrm{L}$ ). Also, water with high metal concentrations stains faucets and sinks. Water used by municipalities with treatment systems may be capable of removing certain harmful constituents or reducing their concentrations via existing processes $[100,188]$.

5.3.3. Aquaculture and Hydroponic Vegetable Culture. Greenhouse experiments were conducted to raise vegetables and fish using either produced water or potable water [201]. In a system using a combination of hydroponic plant cultivation and aquaculture, tomatoes grown with OGPW were smaller than those grown in potable water. The produced water tank grew a larger weight of tilapia (Oreochromis niloticus/aureus); however, some fish died, while none in the potable water tank died [100].

5.3.4. Constructed Wetlands. Constructed wetlands were developed approximately 50 years ago to exploit the ability of plants to treat contaminants in aqueous ecosystems [202]. Advantages of these systems include low construction and operation costs $[188,202]$ and public acceptance. Wetlands provide significant environmental benefits - they can be used by wetland birds and animals as well as by aquatic life. Wetlands can also be utilized for livestock and wildlife watering purposes $[1,203]$.

An artificial sedge wetland system was constructed to treat produced water [14]. After one year of operation the wetland effectively treated $\mathrm{Fe}$ and, to a lesser extent, $\mathrm{Ba}$ $[188,204]$; however, SAR increased from 12.1 to 14.1. This was attributed to calcite precipitation without associated dissolution of $\mathrm{Ca}$ and $\mathrm{Mg}$ [204]. It was concluded that "clean water is needed to supplement sodicity and salinity treatment by vegetation and soil" [205].
5.3.5. Livestock Watering/Confined Animal Feeding Operations (CAFO). The water needs of CAFOs include animal consumption, irrigation of forage crops, and waste management. Livestock watering is one of the most common and proven beneficial uses of produced water [177].

The quality of OGPW presents the greatest constraint for use of livestock watering. Livestock are known to tolerate a range of contaminants in their drinking water. ALL [188] provides data showing acceptable TDS levels for livestock watering. In general, animals may tolerate higher TDS if they are gradually acclimated to the elevated levels. Water with TDS $<1,000 \mathrm{mg} / \mathrm{L}$ is considered excellent source water. Water with TDS from 1,000 to 7,000 mg/L can be used for livestock but may cause digestive problems [188]. Water with TDS of 10,000 is considered unsatisfactory for animal consumption.

5.3.6. Wildlife. Some Rocky Mountain area gas projects have created impoundments measuring at least several acres that collect and retain large volumes of produced water. These impoundments provide a source of drinking water for wildlife and offer habitat for fish and waterfowl and can provide additional recreational opportunities [100]. In some areas, watering ponds provide wintering areas for migrating waterfowl, neotropical birds, or other transient species. In severe drought conditions, watering ponds are used to provide water for large mammals and other wildlife. At Custer Lake, Wyoming, approximately 30,000 barrels of water per day are discharged to what would normally be a seasonal playa lake. Waterfowl and big game are reported to flourish there [177].

The quality of OGPW may limit the use of this management practice, as contaminants may adversely affect fish and wildlife. Research conducted by the USGS has demonstrated acute and chronic sodium bicarbonate toxicity to aquatic species [206]. Coal bed methane-produced water discharges containing Se in concentrations $>2 \mu \mathrm{g} / \mathrm{L}$ may cause bioaccumulation in sensitive species $[1,206]$. Water with TDS $>10,000 \mathrm{mg} / \mathrm{L}$ is not of sufficient quality for wildlife consumption.

5.3.7. Reuse in Oil and Gas Operations. Water is required for a range of day-to-day operations in the oil and gas industries. Activities such as well completions and truck washing may not require water to be of high quality. Therefore, OGPW can be used with little concern for water quality. Minimally treated produced water may be reused by petroleum operators for drilling operations.

Lebas et al. [51] found that produced water with TDS levels as high as $285,000 \mathrm{mg} / \mathrm{L}$ ( $28.5 \%$ salinity) could generate proper cross-linked rheology for hydraulic fracturing consistent with wells that were fracturing with just $20,000 \mathrm{mg} / \mathrm{L}$. A mixture of common drilling chemicals including carboxymethyl hydroxypropyl guar gum, a Zr-based crosslinker, sodium chlorite breakers, and nonemulsified surfactants was blended with $100 \%$ treated OGPW to generate HF fluid that performed as well as that expected from a fluid based on fresh water. The fluids were used to complete seven wells in New Mexico's Delaware basin. The study showed that OGPW possesses all the characteristics required for effective HF, that is, easy preparation, rapid hydration, low 
fluid loss, good proppant transport capacity, low pipe friction, and effective recovery from the reservoir. Lebas et al. [51] state that, in addition to preserving fresh water for agricultural and commercial use, employing produced water for HF can help reduce approximately 1400 truck-loads from the roads and all but eliminate the use of disposal wells.

Erskine et al. [207] report on the use of produced water for drilling projects in New Mexico's San Juan Basin. The authors state that a combination of advection and dilution reduced $\mathrm{Cl}$ concentrations of $10,000 \mathrm{mg} / \mathrm{L}$ to $<1 \mathrm{mg} / \mathrm{L}$ in one year. In the Powder River Basin of Wyoming a water truck load-out facility utilizes produced water for oil and gas well operations, thus taking some pressure off the local water supply to meet this demand. In the Barnett Shale play (Texas) as much as 2 million gallons of make-up water is required for a fracture job. This water is subsequently produced back to the surface in the early stages of development. To reduce the cost of fracturing wells, the produced water is reclaimed and recycled by using it to fracture the next well. In the Battle Creek play (Montana), a zero-discharge system was developed to manage produced water through enhanced evaporation ponds coupled with recycling the produced water for well completion and dust prevention [177].

The main constraint to using produced water for oil and gas operations is the fact that the volume of water used may be modest when compared to the total volume of OGPW produced; therefore, it may be uneconomical to put practices in place solely for recycling produced water for operational uses. This can be overcome by formulating a set of water management practices, where the water is readily available for operations, but for additional purposes as needed [177].

5.3.8. Other Uses/Fire Control. In the Western USA, only limited surface and ground water resources may be available for firefighting. Application of large volumes of saline produced water may adversely impact soil quality to some degree; however, this impact is less devastating than that from a large fire. ALL [188] reports that firefighters near Durango, Colorado, used produced water impoundments as sources of water for firefighting.

5.4. Technologies for Treatment of OGPW. Where reuse of OGPW is practical, authorized by regulatory agencies, and cost-effective, it constitutes a beneficial use of what would otherwise be considered a waste [178]. Beneficial use of produced water may require significant treatment [83]. The primary objectives for treating produced water include desalinization; removal of dispersed oil and grease, suspended particles and sand, soluble organic compounds, dissolved gases, and naturally occurring radioactive material; disinfection; and softening (i.e., to remove excess water hardness) $[83,208]$.

The optimal wastewater treatment technologies available are not able to strip all toxic chemicals from OGPW and are often selectively implemented due to cost [100,184]. A range of dedicated and combined physical, biological, and chemical treatment processes have been developed to treat OGPW. Some popular technologies are reviewed here.

\subsubsection{Membrane Processes for Removal of TDS}

(1) Membrane Filtration. Membrane separation processes available for treating OGPW include microfiltration (MF), ultrafiltration (UF), nanofiltration (NF), and reverse osmosis (RO) [209]. Membranes are microporous films with specific pore sizes which selectively separate components from a fluid. MF uses the largest pore size $(0.1-3 \mathrm{~mm})$ and is typically employed for removal of suspended solids and turbidity reduction. UF pore sizes are between 0.01 and $0.1 \mathrm{~mm}$; this technology is employed for removal of color, odor, viruses, and colloidal organic matter [189, 210, 211]. UF is the most effective method for oil removal from produced water as compared with conventional separation methods [212]. UF is more efficient than MF for removal of hydrocarbons, suspended solids, and dissolved constituents from oilfield produced water [213].

NF is a successful technology for water softening and metals removal and is designed to remove contaminants as small as $0.001 \mathrm{~mm}$ [189]. NF is selective for multivalent ions such as $\mathrm{Ca}^{2+}$ and $\mathrm{Mg}^{2+}$ [214]. It is applicable for treating water containing TDS in the range of $500-25,000 \mathrm{mg} / \mathrm{L}$. NF membranes have been employed for produced water treatment on both bench and pilot scales [209, 215]. Mondal and Wickramasinghe [216] studied the effectiveness of NF membranes for treatment of oilfield produced water. Effectiveness of treatment of brackish feed water was similar between NF and RO techniques [83].

(2) Ceramic Membranes. Ceramic UF/MF membranes have been used in a full-scale facility for treatment of produced water [189]. Treated product water was reported to be free of suspended solids and nearly all nondissolved organic carbon [217-223]. Ceramic UF/MF membranes have a lifespan of about 10 years. Chemicals are not required for this technology except during cleaning of membranes [83].

(3) Reverse Osmosis. RO is a pressure-driven membrane processes. Osmotic pressure of the feed solution is suppressed by applying hydraulic pressure whose forces permeate (i.e., clean water) to diffuse through a dense, nonporous membrane [224]. The major disadvantage of the technology is membrane fouling and scaling $[189,225]$. Nicolaisen and Lien [226] reported successful RO treatment of oilfield OGPW in Bakersfield, California. The pilot system was operated for over 6 months and produced 20 gpm of clean water. A process for converting oilfield produced water into irrigation/drinking quality water consisted of air flotation, clarification, softening, filtration, $\mathrm{RO}$, and water reconditioning [227]. A pilot plant handled water with approximately 7,000 mg/L TDS, $250 \mathrm{mg} / \mathrm{L}$ silica, and $170 \mathrm{mg} / \mathrm{L}$ soluble oil, ranging in $\mathrm{pH}$ from 7 to 11 . The major source of fouling of RO membranes was from organics in the feed water, including organic sulfur compounds. A portion of these entered the RO system as TSS and some precipitated. The quality of treated water met the stringent California Title 22 Drinking Water Maximum Contaminant Levels [227].

RO membrane technology should be appropriate for treating oilfield produced water with appropriate 
pretreatment technology [200]. RO membrane systems generally have a life expectancy of 3-7 years [189].

(4) Electrodialysis/Electrodialysis Reversal. Electrodialysis (ED) and ED reversal (EDR) are well-established desalination technologies. These electrochemically driven processes separate dissolved ions from water through ion exchange membranes. A series of membranes containing electrically charged functional sites are arranged in an alternating mode between an anode and a cathode to remove charged substances from feed water [189]. EDR and ED technologies have been tested at the laboratory-scale for treatment of produced water. Sirivedhin et al. [87] reported that ED is an excellent produced water treatment technology; however, it works optimally for treating relatively low-saline produced water.

The ED/EDR membrane lifetime is between 4 and 5 years. Major limitations of this technology are regular membrane fouling and high treatment cost [189].

(5) Biological Aerated Filters. Biological aerated filtration (BAF) consists of permeable media under aerobic conditions to facilitate biochemical oxidation and removal of organic constituents in wastewater. Media do not exceed $10 \mathrm{~cm}$ in diameter to prevent clogging of pore spaces when sloughing occurs [228]. BAF can remove oil, ammonia, suspended solids, nitrogen, BOD, COD, heavy metals, Fe, soluble organics, trace organics, and $\mathrm{H}_{2} \mathrm{~S}$ from produced water $[189,229]$. Removal efficiencies of up to $70 \% \mathrm{~N}, 80 \%$ oil, $60 \%$ COD, $95 \%$ BOD, and $85 \%$ TSS have been achieved with BAF treatment [229]. Water recovery is nearly $100 \%$ since waste generated is removed in solid form [230]. The method is most effective for produced water with $\mathrm{Cl}$ levels $<6600 \mathrm{mg} / \mathrm{L}$ [189].

BAF systems usually have a long lifespan; they do not require any chemicals or cleaning during normal operations. Accumulated sludges are captured in sedimentation basins. Solid waste disposal can account for up to $40 \%$ of the total cost of this technology [228].

(6) Vibrating Membrane Process. The vibrating membrane process VSEP ${ }^{\circledR}$ (Vibratory Shear Enhanced Process) limits membrane fouling, removing the main contaminants from wastewater without the addition of antiscalant chemical substances. The design greatly reduces the fouling common to all membrane processes [231]. The pressure vessel moves in a vigorous vibratory motion, tangential to membrane surface, thus creating shear waves which prevent membrane fouling $[232,233]$. RO may be implemented as tertiary treatment.

\subsection{Thermal Technologies for Removing Oil and \\ Grease Content}

5.5.1. Multistage Flash (MSF). MSF distillation involves evaporation of water by reducing atmospheric pressure instead of raising temperature. Feed water is preheated and flows into a chamber with reduced air pressure where it immediately flashes into steam [234]. Water recovery from MSF treatment is approx. 20\%; it often requires posttreatment because it typically contains $2-10 \mathrm{mg} / \mathrm{L}$ TDS [189]. A setback in operating MSF is scale formation on heat transfer surfaces which often requires the use of scale inhibitors and acids. MSF is a relatively cost-effective treatment method with plant life expectancy of more than 20 years [235].

5.5.2. Multieffect Distillation. The MED process involves application of energy that converts saline water into steam, which is condensed and recovered as pure water. Multiple effects are employed in order to improve the efficiency and minimize energy consumption. A major advantage of this system is the energy efficiency gained through the combination of several evaporator systems.

MED is suitable for treatment of high TDS produced water $[189,236]$. Product water recovery from MED systems ranges from 20 to $67 \%$ depending on design [234]. Despite the high water recovery, MED has not been extensively used for water production like MSF because of scaling problems associated with early designs. Recently, falling film evaporators have been introduced to improve heat transfer rates and reduce the rate of scale formation [236]. Scale inhibitors and acids may be required to prevent scaling, and $\mathrm{pH}$ control is essential to prevent corrosion. MED has a lifespan of 20 years and can be applied to a wide range of feed water qualities, similar to MSF.

5.5.3. Vapor Compression Distillation. The VCD process is an established desalination technology for treating seawater and RO concentrate [189]. Vapor generated in the evaporation chamber is compressed thermally or mechanically, which raises the temperature and pressure of the vapor. The heat of condensation is returned to the evaporator and is used as a heat source. VCD can operate at temperatures below $70^{\circ} \mathrm{C}$, which reduces scale formation problems [237]. Energy consumption of a VCD plant is significantly lower than that of MED and MSF. Although this technology is mainly associated with sea water desalination, various enhanced vapor compression technologies have been employed for produced water treatment [189].

5.5.4. Multieffect Distillation-Vapor Compression Hybrid. Multistage flash (MSF) distillation, vapor compression distillation (VCD) and multieffect distillation (MED) are extensively used thermal desalination technologies [234]; however, hybrid thermal desalination plants, that is, MED-VCD, have achieved higher efficiencies [236]. Increased production and enhanced energy efficiency are major advantages of this system [189]. GE has developed produced water evaporators which use mechanical vapor compression. These evaporators exhibit a number of advantages over conventional produced water treatment methods including reduction in chemical use, overall cost, fouling severity, and handling [238].

Membrane technologies are often preferred over thermal technologies; however, recent innovations in thermal process engineering have made the latter more competitive in treating highly contaminated water $[83,189,235]$.

Gradiant Corporation (Woburn, MA) is attempting to make HF a "water-neutral process" by reusing water for the HF process. The technology, carrier gas extraction (CGE), is a humidification and dehumidification technique; 
it heats produced water into vapor and condenses it back to contaminant-free water. This process yields freshwater and saturated brine [239].

5.5.5. Freeze Thaw Evaporation. The FTEw process employs freezing, thawing, and conventional evaporation for produced water management. When produced water is cooled below $32^{\circ} \mathrm{F}$ but above its freezing point, relatively pure ice crystals and an unfrozen solution form. The solution contains high concentrations of dissolved constituents and is drained from the ice. The ice is collected and melted to produce clean water.

FTEw can remove $>90 \%$ of TDS, TSS, volatile and semivolatile organics, total recoverable petroleum hydrocarbons, and heavy metals in produced water [220, 240]. FTE requires no chemical additives, infrastructure, or supplies that might restrict its use. It is easy to operate and monitor and has a life expectancy of approximately 20 years [189]. However, the technology can only work in a climate that has a substantial number of days with temperatures below freezing and requires significant land area. FTE technology generates a significant amount of concentrated brine and oil; therefore, waste management and disposal must be addressed.

5.5.6. Dewvaporation: AltelaRain ${ }^{S M}$ Process. The principle of operation of Dewvaporation is based on counter current heat exchange to produce distilled water [241]. Feed water is evaporated in one chamber and condenses in the opposite chamber of a heat transfer wall as distilled water. Approximately $100 \mathrm{bbl} /$ day of produced water with salt concentrations $>60,000 \mathrm{mg} / \mathrm{L}$ TDS can be processed [165]. High removal rates of organics, heavy metals, and radionuclides from produced water have been reported for this technology. In one plant, $\mathrm{Cl}^{-}$concentration was reduced from 25,300 to $59 \mathrm{mg} / \mathrm{L}$, TDS was reduced from 41,700 to $106 \mathrm{mg} / \mathrm{L}$, and benzene concentration was reduced from $450 \mathrm{mg} / \mathrm{L}$ to nondetectable after treatment with AlterRain ${ }^{\mathrm{SM}}$ Dewvaporation technology [242].

\subsection{Physical Separation Technologies}

5.6.1. Hydrocyclones. Hydrocyclones physically separate solids from liquids; hydrocyclones can remove particles in the $5-15 \mathrm{~mm}$ range and have been widely used for treatment of OGPW [189, 243].

Hydrocyclones are used in combination with other technologies as a pretreatment process. They have a long lifespan and do not require chemical use or pretreatment of feed water. A major disadvantage of this technology is generation of substantial slurry of concentrated solid waste.

5.6.2. Gas Flotation. Flotation technology is extensively used for treatment of conventional oilfield produced water.

Flotation technology uses fine gas bubbles to separate suspended particles that are not easily separated by sedimentation. When gas is injected into produced water, suspended particulates and oil droplets become attached to air bubbles as they rise. This results in the formation of foam on the water surface which is skimmed off [244]. Flotation can be used to remove grease and oil, natural organic matter, volatile organics, and small particles from produced water $[50,189$, $243,245]$.

Two types of gas flotation technology are in use, that is, dissolved gas flotation and induced gas flotation, based on the method of gas bubble generation and resultant bubble sizes. Gas flotation can remove particles as small as $25 \mathrm{~mm}$ but cannot remove soluble oil constituents from water [189]. Flotation is most effective when gas bubble size is smaller than oil droplet size. It is expected to work best at low temperature since the process involves dissolving gas into a water stream. The technology does not require chemical use, except for coagulation chemicals that are added to enhance removal of target contaminants. Solids disposal is necessary for the sludge generated from this process.

5.6.3. Media Filtration. Filtration technology is used for removal of oil and grease and total organic carbon (TOC) from produced water [189]. Filtration is carried out using various media such as sand, gravel, anthracite, and walnut shells. This process is not affected by salinity levels and may be applied to any type of produced water. Media filtration technology is highly efficient for removal of oil and grease; efficiency of $>90 \%$ has been reported [189]. Efficiency can be further enhanced if coagulants are added to the feed water prior to filtration. Media regeneration and solid waste disposal are drawbacks to this technology.

5.6.4. Adsorption. Adsorption is generally used as a polishing step in the OGPW treatment process rather than as a standalone technology, since adsorbents can be overloaded with organics. Adsorption is used to remove Mn, Fe, TOC, BTEX, oil, and more than $80 \%$ of heavy metals present in produced water [189]. A wide range of adsorbents is available including activated carbon, organoclays, activated alumina, and zeolites [246]. Adsorption processes are successfully applied to water treatment regardless of salinity. Replacement or regeneration of the sorption media may be required depending on feed water quality and media type $[189,246]$. Chemicals are used to regenerate media when all active sites are blocked.

5.6.5. Ion Exchange Technology. Ion exchange technology is in demand for numerous industrial operations including treatment of OGPW. It is especially useful in the removal of monovalent and divalent ions and metals from produced water [247]. Ion exchange technology has a lifespan of about 8 years and requires pretreatment for solids removal. It also requires chemicals for resin regeneration and disinfection [181].

5.6.6. Macroporous Polymer Extraction Technology. Macroporous polymer extraction (MPPE) is a liquid-liquid extraction technology where the extraction liquid is immobilized within polymer particles impregnated with macropores. The particles have pore sizes of $0.1-10 \mathrm{~mm}$ and a porosity of $60-$ $70 \%$. The polymers were initially designed for absorbing oil from water but later applied to produced water treatment [248]. In the MPPE unit, produced water is passed through a column packed with MPPE particles containing a specific 
extraction liquid. The immobilized extraction liquid removes hydrocarbons from the produced water [71].

In a commercial unit, MPPE was used for removal of dissolved and dispersed hydrocarbons and achieved 99\% removal of BTEX, PAHs, and aliphatic hydrocarbons at 300$800 \mathrm{mg} / \mathrm{L}$ influent concentration. It had a removal efficiency of $95-99 \%$ for aliphatics below $C_{20}$ and it was reported that total aliphatic removal efficiency of 91-95\% was feasible [249].

The hydrocarbons recovered from the MPPE process can be disposed or recycled. Stripped hydrocarbons can be condensed and separated from feed water by gravity, and product water is either discharged or reused. This technology can withstand produced water high in salinity and containing methanol, glycols, corrosion inhibitors, scale inhibitors, $\mathrm{H}_{2} \mathrm{~S}$ scavengers, demulsifiers, defoamers, and dissolved heavy metals [83].

\section{Conclusions}

This review paper has described the composition of oil and gas produced water including common HF additives and documented several key effects on soil properties. Beneficial use of OGPW must take into consideration its chemical make-up, the properties of the recipient soil, and long-term land use objectives. For example, it has been shown that untreated OGPW may be directly applied to the land surface with limited adverse effects. In others, where the water is to be used for domestic or industrial purposes, extensive treatment is required. There is a significant need for further field studies, in particular the study of complex mixtures and how interactions between individual OGPW chemicals influence their environmental fate.

Future OGPW management technologies are likely to focus on (1) capturing secondary value from repurposed water; (2) minimizing transportation; (3) minimizing energy inputs; and (4) reduced air emissions (including $\mathrm{CO}_{2}$ ) all the while with a vision to reduce overall management costs.

\section{Conflict of Interests}

The author declares that there is no conflict of interests regarding the publication of this paper.

\section{References}

[1] Aqwatec, Produced Water Beneficial Use Case Studies, Produced Water Treatment and Beneficial Use Information Center, 2015, http://aqwatec.mines.edu/produced_water/assessbu/case/.

[2] Unconventional Oil and Gas Report (UOGR), Unconventional Resources, 2015, http://www.ogj.com/unconventional-resources .html.

[3] Earthworks, "Hydraulic Fracturing 101. Hydraulic fracturingWhat it is," 2015, https://www.earthworksaction.org/issues/detail/hydraulic_fracturing_101\#.Vi4kGSv6G0I.

[4] L. Britt, "Fracture stimulation fundamentals," Journal of Natural Gas Science and Engineering, vol. 8, pp. 34-51, 2012.

[5] M. J. Economides and K. G. Nolte, Reservoir Stimulation, John Wiley \& Sons, Chichester, UK, 3rd edition, 2000.
[6] R. A. Kerr, "Natural gas from shale bursts onto the scene," Science, vol. 328, no. 5986, pp. 1624-1626, 2010.

[7] H. A. Waxman, E. J. Markey, and D. DeGette, United States House of Representatives. Committee on Energy and Commerce. Chemicals Used In Hydraulic Fracturing, Government Printing Office, Washington, DC, USA, 2011.

[8] H. J. Wiseman, "Untested waters: the rise of hydraulic fracturing in oil and gas production and the need to revisit regulation," Fordham Environmental Law Review, vol. 20, pp. 115-169, 2008.

[9] M. Ratner and M. Tiemann, An Overview of Unconventional Oil and Natural Gas: Resources and Federal Actions, Congressional Research Service, Washington, DC, USA, 2015.

[10] E. Gruber, Recycling Produced \& Flowback Wastewater for Fracking, 2013, http://blog.ecologixsystems.com/wp-content/ uploads/2013/04/Recycling-Produced-and-Flowback-Waterfor-Fracking.pdf.

[11] U.S. Environmental Protection Agency, "Assessment of the potential impacts of hydraulic fracturing for oil and gas on drinking water resources," EPA/600/R-15/047a, 2015, http:// cfpub.epa.gov/ncea/hfstudy/recordisplay.cfm?deid=244651.

[12] C. D. Kassotis, D. E. Tillitt, C.-H. Lin, J. A. McElroy, and S. C. Nagel, "Endocrine-disrupting chemicals and oil and natural gas operations: potential environmental contamination and recommendations to assess complex environmental mixtures," Environmental Health Perspectives, 2015.

[13] J. Deutch, S. Holditch, F. Krupp et al., "The Secretary of the Energy Board Shale Gas Production Subcommittee Ninety-Day Report," 2001, https://www.edf.org/sites/default/ files/11903_Embargoed_Final_90_day_Report\%20.pdf.

[14] B. E. Fontenot, L. R. Hunt, Z. L. Hildenbrand et al., "An evaluation of water quality in private drinking water wells near natural gas extraction sites in the Barnett shale formation," Environmental Science \& Technology, vol. 47, no. 17, pp. 1003210040, 2013.

[15] J. S. Harkness, G. S. Dwyer, N. R. Warner, K. M. Parker, W. A. Mitch, and A. Vengosh, "Iodide, bromide, and ammonium in hydraulic fracturing and oil and gas wastewaters: environmental implications," Environmental Science \& Technology, vol. 49, no. 3, pp. 1955-1963, 2015.

[16] T. G. Harvey, T. W. Matheson, and K. C. Pratt, "Chemical class separation of organics in shale oil by thin-layer chromatography," Analytical Chemistry, vol. 56, no. 8, pp. 1277-1281, 1984.

[17] A. L. Maule, C. M. Makey, E. B. Benson, I. J. Burrows, and M. K. Scammell, "Disclosure of hydraulic fracturing fluid chemical additives: analysis of regulations," New Solutions, vol. 23, no. 1, pp. 167-187, 2013.

[18] N. R. Warner, R. B. Jackson, T. H. Darrah et al., "Geochemical evidence for possible natural migration of Marcellus formation brine to shallow aquifers in Pennsylvania," Proceedings of the National Academy of Sciences of the United States of America, vol. 109, no. 30, pp. 11961-11966, 2012.

[19] B. Ong, "The potential impacts of hydraulic fracturing on agriculture," European Journal of Sustainable Development, vol. 3, no. 3, pp. 63-72, 2014.

[20] K. R. Gilmore, R. L. Hupp, and J. Glathar, "Transport of hydraulic fracturing water and wastes in the susquehanna river basin, Pennsylvania," Journal of Environmental Engineering, vol. 140, no. 5, pp. 10-21, 2014.

[21] D. S. Lee, J. D. Herman, D. Elsworth, H. T. Kim, and H. S. Lee, "A critical evaluation of unconventional gas recovery from the marcellus shale, northeastern United States," KSCE Journal of Civil Engineering, vol. 15, no. 4, pp. 679-687, 2011. 
[22] A. Bergman, J. J. Heindel, S. Jobling, K. A. Kidd, and R. T. Zoeller, "State of the science of endocrine disrupting chemicals 2012," World Health Organization, 2013, http://www.who.int/ ceh/publications/endocrine/en/.

[23] E. Diamanti-Kandarakis, J.-P. Bourguignon, L. C. Giudice et al., "Endocrine-disrupting chemicals: an endocrine society scientific statement," Endocrine Reviews, vol. 30, no. 4, pp. 293342, 2009.

[24] R. Zoeller, Å. Bergman, G. Becher et al., "A path forward in the debate over health impacts of endocrine disrupting chemicals," Environmental Health, vol. 13, article 118, 2014.

[25] S. B. C. Shonkoff, J. Hays, and M. L. Finkel, "Environmental public health dimensions of shale and tight gas development," Environmental Health Perspectives, vol. 122, no. 8, pp. 787-795, 2014.

[26] S. Souther, M. W. Tingley, V. D. Popescu et al., "Biotic impacts of energy development from shale: research priorities and knowledge gaps," Frontiers in Ecology and the Environment, vol. 12, no. 6, pp. 330-338, 2014.

[27] O. Braga, G. A. Smythe, A. I. Schafer, and A. J. Feitz, "Steroid estrogens in primary and tertiary wastewater treatment plants," Water Science and Technology, vol. 52, no. 8, pp. 273-278, 2005.

[28] C. G. Campbell, S. E. Borglin, F. B. Green, A. Grayson, E. Wozei, and W. T. Stringfellow, "Biologically directed environmental monitoring, fate, and transport of estrogenic endocrine disrupting compounds in water: a review," Chemosphere, vol. 65, no. 8 , pp. 1265-1280, 2006.

[29] P. Westerhoff, Y. Yoon, S. Snyder, and E. Wert, "Fate of endocrine-disruptor, pharmaceutical, and personal care product chemicals during simulated drinking water treatment processes," Environmental Science \& Technology, vol. 39, no. 17, pp. 6649-6663, 2005.

[30] K. J. Ferrar, D. R. Michanowicz, C. L. Christen, N. Mulcahy, S. L. Malone, and R. K. Sharma, "Assessment of effluent contaminants from three facilities discharging marcellus shale wastewater to surface waters in Pennsylvania," Environmental Science \& Technology, vol. 47, no. 7, pp. 3472-3481, 2013.

[31] N. R. Warner, C. A. Christie, R. B. Jackson, and A. Vengosh, "Impacts of shale gas wastewater disposal on water quality in Western Pennsylvania," Environmental Science and Technology, vol. 47, no. 20, pp. 11849-11857, 2013.

[32] Natural Resources Defense Council (NRDC), Fracking's Most Wanted: Lifting the Veil on Oil and Gas Company Spills and Violations, IP:15-01-A, 2015, http://www.nrdc.org/land/drilling/ files/fracking-company-violations-IP.pdf.

[33] M. Soraghan, Oil and Gas: Spills up 17 Percent in U.S. in 2013, Environment \& Energy Publishing, 2014, http://www.eenews .net/stories/1059999364.

[34] S. A. Gross, H. J. Avens, A. M. Banducci, J. Sahmel, J. M. Panko, and B. E. Tvermoes, "Analysis of BTEX groundwater concentrations from surface spills associated with hydraulic fracturing operations," Journal of the Air \& Waste Management Association, vol. 63, no. 4, pp. 424-432, 2013.

[35] P. F. Ziemkiewicz, J. D. Quaranta, A. Darnell, and R. Wise, "Exposure pathways related to shale gas development and procedures for reducing environmental and public risk," Journal of Natural Gas Science and Engineering, vol. 16, pp. 77-84, 2014.

[36] D. Sontag and R. Gebeloff, "The downside of the boom," The New York Times, 2014, http://www.nytimes.com/images/ 2014/11/23/nytfrontpage/scan.pdf.

[37] Alberta Environment, "Salt Contamination Assessment \& Remediation Guidelines," Environmental Sciences Division,
Environmental Service, 2001, http://environment.gov.ab.ca/info/library/6144.pdf.

[38] R. B. Jackson, A. Vengosh, T. H. Darrah et al., "Increased stray gas abundance in a subset of drinking water wells near Marcellus shale gas extraction," Proceedings of the National Academy of Sciences of the United States of America, vol. 110, no. 28, pp. 11250-11255, 2013.

[39] S. G. Osborn, A. Vengosh, N. R. Warner, and R. B. Jackson, "Methane contamination of drinking water accompanying gas-well drilling and hydraulic fracturing," Proceedings of the National Academy of Sciences of the United States of America, vol. 108, no. 20, pp. 8172-8176, 2011.

[40] A. Vengosh, R. B. Jackson, N. Warner, T. H. Darrah, and A. Kondash, "A critical review of the risks to water resources from unconventional shale gas development and hydraulic fracturing in the United States," Environmental Science \& Technology, vol. 48, no. 15, pp. 8334-8348, 2014.

[41] S. L. Brantley, D. Yoxtheimer, S. Arjmand et al., "Water resource impacts during unconventional shale gas development: the Pennsylvania experience," The International Journal of Coal Geology, vol. 126, pp. 140-156, 2014.

[42] G. A. Burton Jr., N. Basu, B. R. Ellis, K. E. Kapo, S. Entrekin, and K. Nadelhoffer, "Hydraulic 'fracking': are surface water impacts an ecological concern?" Environmental Toxicology and Chemistry, vol. 33, no. 8, pp. 1679-1689, 2014.

[43] Environmental and Energy Study Institute (EESI), Shale Gas and Oil Terminology Explained: Technology, Inputs \& Operations, EESI, Washington, DC, USA, 2011.

[44] Ostroff Law, "Dangerous fracking chemicals," 2015, http:// frackinginjurylaw.com/dangerous-fracking-chemicals/.

[45] FracFocus.org, "Chemical Use in Hydraulic Fracturing," 2015, http://fracfocus.org/, http://www.fiercewater.com/story/ business-booming-fracking-wastewater/2015-07-28.

[46] W. T. Stringfellow, J. K. Domen, M. K. Camarillo, W. L. Sandelin, and S. Borglin, "Physical, chemical, and biological characteristics of compounds used in hydraulic fracturing," Journal of Hazardous Materials, vol. 275, pp. 37-54, 2014.

[47] US Environmental Protection Agency, "Hydraulic fracturing fluids," in Evaluation of Impacts to Underground Sources of Drinking Water by Hydraulic Fracturing of Coalbed Methane Reservoirs, EPA 816-R- 04-003, US Environmental Protection Agency, Washington, DC, USA, 2004.

[48] Halliburton Energy Services, GBW-30 Breaker MSDS, Halliburton Energy Services, Duncan, Okla, USA, 2009.

[49] A. Fakhru'l-Razi, A. Pendashteh, L. C. Abdullah, D. R. A. Biak, S. S. Madaeni, and Z. Z. Abidin, "Review of technologies for oil and gas produced water treatment," Journal of Hazardous Materials, vol. 170, no. 2-3, pp. 530-551, 2009.

[50] J. P. Ray and F. Rainer Engelhardt, Produced Water: Technological/Environmental Issues and Solutions, vol. 46 of Environmental Science Research, Springer, New York, NY, USA, 1992.

[51] R. A. Lebas, T. W. Shahan, P. Lord, and D. Luna, "Development and use of high-TDS recycled produced water for crosslinkedgel-based hydraulic fracturing," in Proceedings of the SPE Hydraulic Fracturing Technology Conference, SPE-163824MS, Society of Petroleum Engineers, The Woodlands, Tex, USA, February 2013, http://www.ftwatersolutions.com/pdfs/ ProducedWaterPaper.pdf.

[52] U.S. Environmental Protection Agency, "Underground Injection Control Well Classes," 2002, http://water.epa.gov/type/ groundwater/uic/wells.cfm. 
[53] B. R. Hansen and S. R. H. Davies, "Review of potential technologies for the removal of dissolved components from produced water," Chemical Engineering Research and Design, vol. 72, pp. 176-188, 1994.

[54] D. Rahm, "Regulating hydraulic fracturing in shale gas plays: the case of Texas," Energy Policy, vol. 39, no. 5, pp. 2974-2981, 2011.

[55] B. G. Rahm, J. T. Bates, L. R. Bertoia, A. E. Galford, D. A. Yoxtheimer, and S. J. Riha, "Wastewater management and Marcellus Shale gas development: trends, drivers, and planning implications," Journal of Environmental Management, vol. 120, pp. 105-113, 2013.

[56] FracFocus, "Hydraulic fracturing-the process," 2015, https:// fracfocus.org/hydraulic-fracturing-how-it-works/hydraulicfracturing-process.

[57] PetroWiki, "Fracturing fluids and additives," 2015, http://petrowiki.org/Fracturing_fluids_and_additives.

[58] R. D. Vidic, S. L. Brantley, J. M. Vandenbossche, D. Yoxtheimer, and J. D. Abad, "Impact of shale gas development on regional water quality," Science, vol. 340, no. 6134, 2013.

[59] S. A. Holditch, Criteria for Propping Agent Selection, Norton Company, Dallas, Tex, USA, 1979.

[60] Saint-Gobain, Products, 2015, http://www.proppants.saintgobain.com/products.

[61] PetroWiki, "Propping agents and fracture conductivity," 2015, http://petrowiki.org/Propping_agents_and_fracture_conductivity.

[62] C. Montgomery, "Fracturing fluid components," in Effective and Sustainable Hydraulic Fracturing, A. P. Bunger, J. McLennan, and R. Jeffrey, Eds., chapter 2, InTech, Vienna, Austria, 2013.

[63] R. Hodge, "Crosslinked and Linear Gel CompositionChemical and Analytical Methods," EPA's Study of Hydraulic Fracturing and Its Potential Impact on Drinking Water Resources, 2015, http://www2.epa.gov/hfstudy/crosslinkedand-linear-gel-composition-chemical-and-analytical-methods.

[64] New York State Department of Environmental Conservation (NYS DEC), Revised Draft Supplemental Generic Environmental Impact Statement on the Oil, Gas and Solution Mining Regulatory Program, Well Permit Issuance for Horizontal Drilling and High-Volume Hydraulic Fracturing in the Marcellus Shale and Other Low-Permeability Gas Reservoirs, New York State Department of Environmental Conservation, Albany, NY, USA, 2011, http://www.dec.ny.gov/energy/75370.html.

[65] ALL Consulting, Ground Water Protection Council, Modern Shale Gas Development in the United States: A Primer, U.S. Department of Energy, Office of Fossil Energy, Washington, DC, USA, 2009.

[66] G. E. King, "Hydraulic fracturing 101: what every representative, environmentalist, regulator, reporter, investor, university researcher, neighbor and engineer should know about estimating frac risk and improving frac performance in unconventional gas and oil wells," in Proceedings of the SPE Hydraulic Fracturing Technology Conference, Society of Petroleum Engineers, The Woodlands, Tex, USA, February 2012.

[67] URS Corporation, "Water-related issues associated with gas production in the Marcellus Shale: additives use, flowback quality and quantities, regulations, on-site treatment, green technologies, alternate water sources, water well-testing," Contract PO 10666, URS Corporation, Fort Washington, Pa, USA, 2011.
[68] R. Barati and J.-T. Liang, "A review of fracturing fluid systems used for hydraulic fracturing of oil and gas wells," Journal of Applied Polymer Science, vol. 131, no. 16, Article ID 40735, 2014.

[69] G. Zimmermann, G. Blöcher, A. Reinicke, and W. Brandt, "Rock specific hydraulic fracturing and matrix acidizing to enhance a geothermal system - concepts and field results," Tectonophysics, vol. 503, no. 1-2, pp. 146-154, 2011.

[70] R. McCurdy, "High rate hydraulic fracturing additives in nonmarcellus unconventional shale," in Proceedings of the Technical Workshops for the Hydraulic Fracturing Study: Chemical of Analytical Methods, U.S. Environmental Protection Agency, Arlington, Va, USA, February 2011.

[71] Akzo Nobel MPP Systems, Macro-Porous Polymer Extraction for Offshore Produced Water Removes Dissolved and Dispersed Hydrocarbons, Business Briefing: Exploration \& Production: The Oil \& Gas Review, Pasadena, Calif, USA, 2004.

[72] A. Aminto and M. S. Olson, "Four-compartment partition model of hazardous components in hydraulic fracturing fluid additives," Journal of Natural Gas Science and Engineering, vol. 7, pp. 16-21, 2012.

[73] A. A. Al-Zahrani, "Innovative method to mix corrosion inhibitor in emulsified acids," in Proceedings of the 6th International Petroleum Technology Conference, Beijing, China, March 2013.

[74] A. Rostami and H. A. Nasr-El-Din, "Review and evaluation of corrosion inhibitors used in well stimulation," in Proceedings of the SPE International Symposium on Oilfield Chemistry, Society of Petroleum Engineers, April 2009.

[75] J. Yang, V. Jovancicevic, S. Mancuso, and J. Mitchell, "High performance batch treating corrosion inhibitor," in Proceedings of the Corrosion Conference \& Expo, NACE International, Nashville, Tenn, USA, March 2007.

[76] M. McHugh, The natural degradation of hydraulic fracturing fluids in the shallow subsurface [Ph.D. thesis], The Ohio State University, Columbus, Ohio, USA, 2015.

[77] M. M. Brezinski, T. R. Gardner, W. M. Harms, J. L. Lane, and K. L. King, "Controlling iron in aqueous well fracturing fluids," US Patent, vol. 5, pp. 674, 817, Halliburton Energy Services, 1997.

[78] K. C. Taylor, H. A. Nasr-El-Din, M. J. Al-Alawi, and S. Aramco, "Systematic study of iron control chemicals used during well stimulation," Society of Petroleum Engineers Journal, vol. 4, pp. 19-24, 1999.

[79] International Energy Agency (IEA), Water Management Associated with Hydraulic Fracturing, AP Guidance Document HF2, International Energy Agency (IEA), Washington, DC, USA, 2010.

[80] W. R. Dill and G. Fredette, "Iron control in the Appalachian basin," in Proceedings of the SPE Eastern Regional Meeting, Society of Petroleum Engineers, Pittsburgh, Pa, USA, November 1983.

[81] Z. Zhou and D. H. S. Law, Swelling Clays in Hydrocarbon Reservoirs: The Bad, the Less Bad, and the Useful, Alberta Research Council, Alberta, Canada, 1998.

[82] T. Strømgren, S. E. Sørstrøm, L. Schou et al., "Acute toxic effects of produced water in relation to chemical composition and dispersion," Marine Environmental Research, vol. 40, no. 2, pp. 147-169, 1995.

[83] E. T. Igunnu and G. Z. Chen, "Produced water treatment technologies," International Journal of Low-Carbon Technologies, vol. 9, no. 3, pp. 157-177, 2014. 
[84] R. R. Reynolds, "Produced water and associated issues: a manual for the independent operator," Oklahoma Geological Survey Open-File Report, vol. 6, pp. 1-56, 2003.

[85] L.-H. Chan, A. Starinsky, and A. Katz, "The behavior of lithium and its isotopes in oilfield brines: evidence from the HeletzKokhav field, Israel," Geochimica et Cosmochimica Acta, vol. 66, no. 4, pp. 615-623, 2002.

[86] T. Hayes and D. Arthur, "Overview of emerging produced water treatment technologies," in Proceedings of the 11th Annual International Petroleum Environmental Conference, Albuquerque, NM, USA, 2004.

[87] T. Sirivedhin, J. McCue, and L. Dallbauman, "Reclaiming produced water for beneficial use: salt removal by electrodialysis," Journal of Membrane Science, vol. 243, no. 1-2, pp. 335-343, 2004.

[88] C. M. Hudgins Jr., "Chemical use in North Sea oil and gas E\&P," Journal of Petroleum Technology, vol. 46, no. 1, pp. 67-74, 1994.

[89] M. E. Blauch, R. R. Myers, T. R. Moore, and B. A. Lipinski, "Marcellus Shale postfrac flowback waters-where is all the salt coming from and what are the implications?" in Proceedings of the Society of Petroleum Engineers Eastern Regional Meeting, SPE 125740, pp. 1-20, Charleston, SC, USA, 2009.

[90] L. O. Haluszczak, A. W. Rose, and L. R. Kump, "Geochemical evaluation of flowback brine from Marcellus gas wells in Pennsylvania, USA," Applied Geochemistry, vol. 28, pp. 55-61, 2013.

[91] C. W. Poth, Occurrence of Brine in Western Pennsylvania, Pennsylvania Geological Survey, Report 47, 4th series, Mineral Resource, 1962.

[92] P. E. Dresel, The geochemistry of oilfield brines from western pennsylvania [M.S. thesis], Pennsylvania State University, 1985.

[93] P. E. Dresel and A. W. Rose, "Chemistry and origin of oil and gas well brines in Western Pennsylvania," Pennsylvania Geological Survey, 4th Series, Open-File Report OFOG 10-01.0, 2010.

[94] R. W. Roach, R. S. Carr, and C. L. Howard, An Assessment of Produced Water Impacts at Two Sites in the Galveston Bay System, United States Fish and Wildlife Service, Clear Lake Field Office, Houston, Tex, USA, 1993.

[95] K. S. E. Al-Malahy and T. Hodgkiess, "Comparative studies of the seawater corrosion behaviour of a range of materials," Desalination, vol. 158, no. 1-3, pp. 35-42, 2003.

[96] E. C. Chapman, R. C. Capo, B. W. Stewart et al., "Geochemical and strontium isotope characterization of produced waters from Marcellus shale natural gas extraction," Environmental Science \& Technology, vol. 46, no. 6, pp. 3545-3553, 2012.

[97] M. A. Cluff, Microbial aspects of shale flowback fluids and response to hydraulic fracturing fluids [M.S. thesis], The Ohio State University, Columbus, Ohio, USA, 2013.

[98] T. Hayes, "Sampling and Analysis of Water Streams Associated with the Development of Marcellus Shale Gas," 2009, http:// energyindepth.org/wp-content/uploads/marcellus/2012/11/ MSCommission-Report.pdf.

[99] T. I. R. Utvik, "Composition, characteristics of produced water in the North Sea," in Proceedings of the Produced Water Workshop, Aberdeen, UK, March 2003.

[100] J. A. Veil, M. G. Puder, D. Elcock et al., A White Paper Describing Produced Water from Production of Crude oil, Natural Gas, and Coal Bed Methane, US. D.O.E, Argonne National Laboratory, 2004.

[101] Nature Technology Group (NTG), Introduction to Produced Water Treatment, Nature Technology Solutions, 2005.
[102] S. J. Maguire-Boyle and A. R. Barron, "Organic compounds in produced waters from shale gas wells," Environmental Sciences: Processes and Impacts, vol. 16, no. 10, pp. 2237-2248, 2014.

[103] M. B. Adams, "Land application of hydrofracturing fluids damages a deciduous forest stand in West Virginia," Journal of Environmental Quality, vol. 40, no. 4, pp. 1340-1344, 2011.

[104] U.S. Environmental Protection Agency, "Presidential green chemistry challenge award recipients 1996-2012," Tech. Rep. 744F12001, EPA, Washington, DC, USA, 2012.

[105] D. J. Rozell and S. J. Reaven, "Water pollution risk associated with natural gas extraction from the Marcellus Shale," Risk Analysis, vol. 32, no. 8, pp. 1382-1393, 2012.

[106] Reuters, "Update 2-Oil well in North Dakota out of control, leaking," 2014, http://www.reuters.com/article/2014/02/14/ energy-crude-blowout-idUSL2N0LJ15820140214.

[107] A. Dalrymple, "ND well blowout leaks 23,000 gallons of oil, but company says minimal damage," InForum, 2015, http://www .eeia.myindustrytracker.com/en/article/73089/nd-well-blowout -leaks-23-000-gallons-of-oil-but-company-says-minimal-damage.

[108] M. Grossi, "Fracking probe extends in Central Valley," Fresno Bee, November 2013.

[109] K. Bullis, “One Way to Solve Fracking's Dirty Problem," MIT Technology Review, 2013.

[110] J. Healy, "After the floods in Colorado, a deluge of worry about leaking oil," The New York Times, 2013.

[111] D. W. Nelson, S. L. Liu, and L. E. Somers, "Extractability and plant uptake of trace elements from drilling fluids," Journal of Environmental Quality, vol. 13, no. 4, pp. 562-566, 1983.

[112] R. W. Miller, S. Honarvar, and B. Hunsaker, "Effects of drilling fluids on soils and plants. I. Individual fluid components," Journal of Environmental Quality, vol. 9, no. 4, pp. 547-552, 1980.

[113] R. W. Miller and P. Pesaran, "Effects of drilling fluids on soils and plants: II. Complete drilling fluid mixtures," Journal of Environmental Quality, vol. 9, no. 4, pp. 552-556, 1980.

[114] Toxnet, "Ethylene glycol," National Library of Medicine, Toxicology Data Network, 2015, http://toxnet.nlm.nih.gov/cgi-bin/ sis/search/a?dbs+hsdb:@term+@DOCNO+5012.

[115] M. McLaughlin, "Fate of hydraulic fracturing chemicals in agricultural topsoil," in Proceedings of the American Chemical Society National Meeting, Denver, Colo, USA, March 2015, http: //presentations.acs.org/common/presentation-detail.aspx/ Spring2015/ENVR/ENVR021a/2139634.

[116] Q. Wen, Z. Chen, Y. Zhao, H. Zhang, and Y. Feng, "Biodegradation of polyacrylamide by bacteria isolated from activated sludge and oil-contaminated soil," Journal of Hazardous Materials, vol. 175, no. 1-3, pp. 955-959, 2010.

[117] L. L. Liu, Z. P. Wang, K. F. Lin, and W. M. Cai, "Microbial degradation of polyacrylamide by aerobic granules," Environmental Technology, vol. 33, no. 9, pp. 1049-1054, 2012.

[118] M. T. Bao, Q. G. Chen, Y. M. Li, and G. C. Jiang, "Biodegradation of partially hydrolyzed polyacrylamide by bacteria isolated from production water after polymer flooding in an oil field," Journal of Hazardous Materials, vol. 184, no. 1-3, pp. 105-110, 2010.

[119] N. C. Brady and R. R. Weil, The Nature and Properties of Soils, Prentice-Hall, New York, NY, USA, 14th edition, 2007.

[120] M. C. Steele and J. Pichtel, "Ex-situ remediation of a metalcontaminated Superfund soil using selective extractants," Journal of Environmental Engineering, vol. 124, no. 7, pp. 639-645, 1998. 
[121] A. J. Francis, "Effects of acidic precipitation and acidity on soil microbial processes," Water, Air, and Soil Pollution, vol. 18, no. 1-3, pp. 375-394, 1982.

[122] U. Tezel, Fate and effect of quaternary ammonium compounds in biological systems [Ph.D. thesis], Georgia Institute of Technology, Atlanta, Ga, USA, 2009.

[123] G.-G. Ying, "Fate, behavior and effects of surfactants and their degradation products in the environment," Environment International, vol. 32, no. 3, pp. 417-431, 2006.

[124] C. Hansch, A. Leo, and D. H. Hoekman, Exploring QSAR, American Chemical Society (ACS), Washington, DC, USA, 1995.

[125] N. Kreuzinger, M. Fuerhacker, S. Scharf, M. Uhl, O. Gans, and B. Grillitsch, "Methodological approach towards the environmental significance of uncharacterized substances-quaternary ammonium compounds as an example," Desalination, vol. 215, no. 1-3, pp. 209-222, 2007.

[126] C. A. M. Bondi, "Applying the precautionary principle to consumer household cleaning product development," Journal of Cleaner Production, vol. 19, no. 5, pp. 429-437, 2011.

[127] M. T. García, I. Ribosa, T. Guindulain, J. Sánchez-Leal, and J. Vives-Rego, "Fate and effect of monoalkyl quaternary ammonium surfactants in the aquatic environment," Environmental Pollution, vol. 111, no. 1, pp. 169-175, 2001.

[128] C. G. van Ginkel, J. B. van Dijk, and A. G. M. Kroon, "Metabolism of hexadecyltrimethylammonium chloride in Pseudomonas Strain-B1," Applied and Environmental Microbiology, vol. 58, no. 9, pp. 3083-3087, 1992.

[129] R. S. Boethling, "Environmental aspects of cationic surfactants," in Cationic Surfactants: Analytical and Biological Evaluation, J. Cross and E. J. Singer, Eds., vol. 53, Marcel Dekker, New York, NY, USA, 1994.

[130] T. Nishihara, T. Okamoto, and N. Nishiyama, "Biodegradation of didecyldimethylammonium chloride by Pseudomonas fluorescens TN4 isolated from activated sludge," Journal of Applied Microbiology, vol. 88, no. 4, pp. 641-647, 2000.

[131] M. A. Patrauchan and P. J. Oriel, "Degradation of benzyldime thylalkylammonium chloride by Aeromonas hydrophila sp," Applied Microbiology, vol. 94, pp. 266-272, 2003.

[132] S. Takenaka, T. Tonoki, K. Taira, S. Murakami, and K. Aoki, "Adaptation of Pseudomonas sp. strain 7-6 to quaternary ammonium compounds and their degradation via dual pathways," Applied and Environmental Microbiology, vol. 73, no. 6, pp. 1799-1802, 2007.

[133] D. McIlwaine, "Challenging traditional biodegradation tests: the biodegradation of glutaraldehyde," 2002, http://ipec.utulsa .edu/Conf2002/mcilwaine_136.pdf.

[134] L. Laopaiboon, N. Phukoetphim, K. Vichitphan, and P. Laopaiboon, "Biodegradation of an aldehyde biocide in rotating biological contactors," World Journal of Microbiology and Biotechnology, vol. 24, no. 9, pp. 1633-1641, 2008.

[135] Toxnet, "Tetrakis(hydroxymethyl) phosphonium sulfate," National Library of Medicine, Toxicology Data Network, 2015, http://toxnet.nlm.nih.gov/cgi-bin/sis/search/a?dbs+hsdb:@ term+@DOCNO+4215.

[136] A. N. Shamim, Scoping Document: Product Chemistry/Environmental Fate/Ecotoxicity of: Tetrakis (Hydroxymethyl) Phosphonium Sulfate, U.S. Environmental Protection Agency (U.S. EPA), Washington, DC, USA, 2011.

[137] S. Groome, "Tetrakis (hydroxymethyl) phosphonium sulfate THPS," Chemistry Document EPA-HQ-OPP-2011-0067, U.S. Environmental Protection Agency, Washington, DC, USA, 2011.
[138] W. J. Lyman, Environmental Exposure from Chemicals, vol. 1, Edited by W. B. Neely and G. E. Blau, CRC Press, Boca Raton, Fla, USA, 1985.

[139] J. H. Exner, G. A. Burk, and D. Kyriacou, "Rates and products of decomposition of 2,2-dibromo-3-nitrilopropionamide," Journal of Agricultural and Food Chemistry, vol. 21, no. 5, pp. 838-846, 1973.

[140] Wiser, "Propargyl Alcohol," 2015, http://webwiser.nlm.nih.gov/ WebWISER/pda/getSubstanceData.do;jsessionid=E0B34CF56185EB60A4EA84DB4E4A255A?substanceId=146\&menuItemID=76\&identifier=Propargyl+Alcohol\&identifierType=Name.

[141] United States Environmental Protection Agency, "Environmental Impact and Benefit Assessment for the Final Effluent Limitation Guidelines and Standards for the Airport Deicing Category," 2006, http://water.epa.gov/scitech/ wastetech/guide/airport/upload/Environmental-Impact-andBenefit-Assessment-for-the-Final-Effluent-Limitation-Guidelines-and-Standards-for-the-Airport-Deicing-Category.pdf.

[142] World Health Organization (WHO), “Thiourea," Concise International Chemical Assessment Document 49, 2003, http://www .who.int/ipcs/publications/cicad/en/cicad49.pdf.

[143] Chemicals Inspection Testing Institute (CITI), Biodegradation and Bioaccumulation Data of Existing Chemicals based on the CSCL Japan, Japan Chemical Industry Ecology-Toxicology and Information Center, Saitama, Japan, 1992.

[144] Toxnet, "Mercaptoacetic acid," National Library of Medicine, Toxicology Data Network, 2015, http://toxnet.nlm.nih.gov/cgibin/sis/search/a?dbs+hsdb:@term+@DOCNO+2702.

[145] R. J. Lewis Sr., Ed., Sax's Dangerous Properties of Industrial Materials, Wiley-Interscience, John Wiley \& Sons, Hoboken, NJ, USA, 11th edition, 2004.

[146] Toxnet, "Hazardous Substance Data Bank (HSDB)," National Library of Medicine, Toxicology Data Network, 2015, http:// toxnet.nlm.nih.gov/cgi-bin/sis/htmlgen?HSDB.

[147] European Chemicals Agency (ECHA) and International Uniform Chemical Information Database (IUCLID), CD-ROM Year 2000 Edition, European Chemicals Agency (ECHA), Helsinki, Finland, 2000.

[148] P. Shrivastava and R. Kumar, "Soil salinity: a serious environmental issue and plant growth promoting bacteria as one of the tools for its alleviation," Saudi Journal of Biological Sciences, vol. 22, no. 2, pp. 123-131, 2015.

[149] M. Ashraf, "Some important physiological selection criteria for salt tolerance in plants," Flora, vol. 199, no. 5, pp. 361-376, 2004.

[150] A. Bano and M. Fatima, "Salt tolerance in Zea mays (L). following inoculation with Rhizobium and Pseudomonas," Biology and Fertility of Soils, vol. 45, no. 4, pp. 405-413, 2009.

[151] R. Munns, "Comparative physiology of salt and water stress," Plant, Cell and Environment, vol. 25, no. 2, pp. 239-250, 2002.

[152] R. Munns and R. A. James, "Screening methods for salinity tolerance: a case study with tetraploid wheat," Plant and Soil, vol. 253, no. 1, pp. 201-218, 2003.

[153] M. Tester and R. Davenport, " $\mathrm{Na}^{+}$tolerance and $\mathrm{Na}^{+}$transport in higher plants," Annals of Botany, vol. 91, no. 5, pp. 503-527, 2003.

[154] S. Tabur and K. Demir, "Role of some growth regulators on cytogenetic activity of barley under salt stress," Plant Growth Regulation, vol. 60, no. 2, pp. 99-104, 2010.

[155] M. G. Javid, A. Sorooshzadeh, F. Moradi, S. A. M. M. Sanavy, and I. Allahdadi, "The role of phytohormones in alleviating salt stress in crop plants," Australian Journal of Crop Science, vol. 5, no. 6, pp. 726-734, 2011. 
[156] T. K. Frost, S. Johnsen, and T. I. Utvik, Environmental Effects of Produced Water Discharges to the Marine Environment, OLF, Norway, 1998, http://www.olf.no/static/en/rapporter/producedwater/summary.html.

[157] D. C. Wolf, K. R. Brye, and E. E. Gbur, "Using soil amendments to increase Bermuda grass growth in soil contaminated with hydraulic fracturing drilling fluid," Soil and Sediment Contamination, vol. 24, no. 8, pp. 846-864, 2015.

[158] M. Ahmad, S. Soo Lee, J. E. Yang, H.-M. Ro, Y. Han Lee, and Y. Sik Ok, "Effects of soil dilution and amendments (mussel shell, cow bone, and biochar) on $\mathrm{Pb}$ availability and phytotoxicity in military shooting range soil," Ecotoxicology and Environmental Safety, vol. 79, pp. 225-231, 2012.

[159] D. Lloyd, "Drilling waste disposal in Alberta," in Proceedings of the National Conference on Disposal of Drilling Wastes, Environmental and Ground Water Institute, Norman, Okla, USA, May 1985.

[160] D. Anderson, "Effective saltwater remediation," NDPC Brine Task Force, Oasis Petroleum, 2015, https://www.ndoil.org/ image/cache/AndersonDustin.pdf.

[161] E. de Jong, The Final Report of a Study Conducted on the Reclamation of Brine and Emulsion Spills in the Cultivated Area of Saskatchewan, Saskatchewan Department of Mineral Resources and the Canadian Petroleum Association, Saskatchewan Division, Saskatchewan, Canada, 1979.

[162] M. E. Sumner, "Sodic soils: new perspectives," Australian Journal of Soil Research, vol. 31, no. 6, pp. 683-750, 1993.

[163] J. Sharma, A. V. Ogram, and A. Al-Agely, Mycorrhizae: Implications for Environmental Remediation and Resource Conservation, IFAS Extension ENH-1086, University of Florida, Gainesville, Fla, USA, 2015, http://ufdcimages.uflib.ufl.edu/IR/ 00/00/17/79/00001/EP35100.pdf.

[164] J. Pichtel, Fundamentals of Site Remediation for Metal- and Hydrocarbon-Contaminated Soils, Government Institutes, Rockville, Md, USA, 2nd edition, 2007.

[165] Energy \& Environmental Research Center (EERC), "Spills Cleanup Primer," BakkenSmart, 2015, http://www.northdakotaoilcan.com/home-menu/news-info/resources/spills-cleanupprimer/.

[166] M. Farhadian, C. Vachelard, D. Duchez, and C. Larroche, "In situ bioremediation of monoaromatic pollutants in groundwater: a review," Bioresource Technology, vol. 99, no. 13, pp. 52965308, 2008.

[167] I. V. Robles-González, F. Fava, and H. M. Poggi-Varaldo, "A review on slurry bioreactors for bioremediation of soils and sediments," Microbial Cell Factories, vol. 7, article 5, 2008.

[168] M. E. Fuller, J. Kruczek, R. L. Schuster, P. L. Sheehan, and P. M. Arienti, "Bioslurry treatment for soils contaminated with very high concentrations of 2,4,6-trinitrophenylmethylnitramine (tetryl)," Journal of Hazardous Materials, vol. 100, no. 1-3, pp. 245-257, 2003.

[169] D. Dean-Ross, "Biodegradation of selected PAH from sediment in bioslurry reactors," Bulletin of Environmental Contamination and Toxicology, vol. 74, no. 1, pp. 32-39, 2005.

[170] O. Ward, A. Singh, and J. Van Hamme, "Accelerated biodegradation of petroleum hydrocarbon waste," Journal of Industrial Microbiology and Biotechnology, vol. 30, no. 5, pp. 260-270, 2003.

[171] C. N. Mulligan, R. N. Yong, and B. F. Gibbs, "Remediation technologies for metal-contaminated soils and groundwater: an evaluation," Engineering Geology, vol. 60, no. 1-4, pp. 193-207, 2001.
[172] S. A. Wasay, S. Barrington, and S. Tokunaga, "Organic acids for the in situ remediation of soils polluted by heavy metals: soil flushing in columns," Water, Air, and Soil Pollution, vol. 127, no. 1-4, pp. 301-314, 2001.

[173] M. N. V. Prasad, "Phytoremediation of metals in the environment for sustainable development," Proceedings of the National Academy of Sciences, India Section B: Biological Sciences, vol. 70, no. 1, pp. 71-98, 2004.

[174] I. Alkorta, J. Hernández-Allica, J. M. Becerril, I. Amezaga, I. Albizu, and C. Garbisu, "Recent findings on the phytoremediation of soils contaminated with environmentally toxic heavy metals and metalloids such as zinc, cadmium, lead, and arsenic," Reviews in Environmental Science and Biotechnology, vol. 3, no. 1, pp. 71-90, 2004.

[175] C. Garbisu, J. Hernández-Allica, O. Barrutia, I. Alkorta, and J. M. Becerril, "Phytoremediation: a technology using green plants to remove contaminants from polluted areas," Reviews on Environmental Health, vol. 17, no. 3, pp. 173-188, 2002.

[176] M. N. V. Prasad, "Phytoremediation of metals and radionuclides in the environment: the case for natural hyperaccumulators, metal transporters, soil-amending chelators and transgenic plants," in Heavy Metal Stress in Plants, M. N. V. Prasad, Ed., chapter 14, pp. 345-391, Springer, Berlin, Germany, 1999.

[177] U.S. Department of Energy, A Guide to Practical Management of Produced Water from Onshore Oil and Gas Operations in the United States, Interstate Oil and Gas Compact Commission and ALL Consulting, 2006, http://www.all-llc.com/ publicdownloads/ALL-PWGuide.pdf.

[178] National Petroleum Council (NPC), "Management of Produced Water from Oil and Gas Wells, Paper \#2-17," NPC North American Resource Development Study, 2011, https://www.npc.org/Prudent_Development-Topic_Papers/2-17 _Management_of_Produced_Water_Paper.pdf.

[179] GRI, "Technology assessment and economic evaluation of downhole gas/water separation and disposal tools," Tech. Rep. GRI-99/0218, Radian Corporation for the Gas Research Institute, Des Plaines, Ill, USA, 1999.

[180] E. I. Shirman and A. K. Wojtanowicz, "More oil using downhole water-sink technology: a feasibility study," SPE 66532, SPE Production and Facilities, 2002.

[181] A. K. Wojtanowicz, E. I. Shirman, and H. Kurban, "Downhole Water Sink (DWS) completions enhance oil recovery in reservoirs with water coning problem," in Proceedings of the SPE Annual Technical Conference and Exhibition, SPE 56721, Houston, Tex, USA, October 1999.

[182] M. Swisher, "Summary of DWS application in Northern Louisiana," in Proceedings of the Downhole Water Separation Technology Workshop, Baton Rouge, La, USA, March 2000.

[183] A. K. Wojtanowicz, "Smart dual completions for downhole water control in oil and gas wells," in Proceedings of the Produced Water Management Workshop, Houston, Tex, USA, April 2003.

[184] L. Shariq, "Uncertainties associated with the reuse of treated hydraulic fracturing wastewater for crop irrigation," Environmental Science and Technology, vol. 47, no. 6, pp. 2435-2436, 2013.

[185] J. D. Arthur, B. G. Langhus, and C. Patel, Technical Summary of Oil \& Gas Produced Water Treatment Technologies, NETL, Tulsa, Okla, USA, 2005.

[186] U.S. Environmental Protection Agency, "Design, construction, and operation of hazardous and nonhazardous waste surface impoundments," Tech. Rep. EPA/530/SW-91/054a, EPA, Cincinnati, Ohio, USA, 1991. 
[187] V. Velmurugan and K. Srithar, "Prospects and scopes of solar pond: a detailed review," Renewable \& Sustainable Energy Reviews, vol. 12, no. 8, pp. 2253-2263, 2008.

[188] ALL Consulting, Handbook on Coal Bed Methane Produced Water: Management and Beneficial Use Alternatives, ALL Consulting, Tulsa, Okla, USA, 2003.

[189] Colorado School of Mines, "Technical assessment of produced water treatment technologies. An integrated framework for treatment and management of produced water," RPSEA Project 07122-12, Golden, Colo, USA, 2009.

[190] Agricultural Water Clearing House (AWCH), FAQ-Water Supply, Sources, \& Agricultural Use, 2015, http://www.agwaterconservation.colostate.edu/FAQs_WaterSupplySourcesAgriculturalUse.aspx\#A1.

[191] A. Horpestad, D. Skaar, and H. Dawson, "Water quality impacts from CBM development in the powder river basin, Wyoming and Montana," Water Quality Technical Report, 2001.

[192] D. B. Burnett and J. A. Veil, "Decision and risk analysis study of the injection of desalination by-products into oil-and gas-producing zones," in Proceedings of the SPE International Symposium and Exhibition on Formation Damage Control, SPE86526-MS, Lafayette, La, USA, February 2004.

[193] The Ground Water Protection Council, "Making water produced during oil and gas operations a managed resource for beneficial uses," in Proceedings of the Ground Water Protection Council Produced Water Conference, Colorado Springs, Colo, USA, October 2002, http://www.gwpc.org/sites/default/files/ events/Agenda.pdf.

[194] International Association of Oil and Gas Producers, "Guidelines for produced water injection," Report 2.80/302, 2002, http://www.ogp.org.uk/pubs/302.pdf.

[195] J. Cart, “Central Valley's growing concern: crops raised with oil field water," Los Angeles Times, 2014, http://www.latimes.com/ local/california/la-me-drought-oil-water-20150503-story.html \#page $=1$.

[196] Wyoming Department of Environmental Quality, UIC Program, 2015, http://deq.wyoming.gov/wqd/underground-injection-control/.

[197] A. J. DeJoia, "Developing sustainable practices for CBMproduced water irrigation," in Proceedings of the Ground Water Protection Council Produced Water Conference, Colorado Springs, Colo, USA, October 2002, http://www.gwpc.org/sites/ default/files/events/Agenda.pdf.

[198] R. J. Paetz and S. Maloney, "Demonstrated economics of managed irrigation for CBM produced water," in Proceedings of the Ground Water Protection Council Produced Water Conference, Colorado Springs, Colo, USA, October 2002, http://www.gwpc .org/sites/default/files/events/Agenda.pdf.

[199] C. R. Bern, G. N. Breit, R. W. Healy, J. W. Zupancic, and R. Hammack, "Deep subsurface drip irrigation using coal-bed sodic water: part I. Water and solute movement," Agricultural Water Management, vol. 118, pp. 122-134, 2013.

[200] R. Chhabra, Soil Salinity and Water Quality, Balkema, Rotterdam, Netherlands, 1996.

[201] L. Jackson and J. Myers, "Alternative use of produced water in aquaculture and hydroponic systems at naval petroleum reserve no. 3," in Proceedings of the Ground Water Protection Council Produced Water Conference, Colorado Springs, Colo, USA, October 2002, http://www.gwpc.org/sites/default/files/events/ Agenda.pdf.
[202] P. F. Cooper, G. F. Job, M. B. Green, and R. B. E. Shutes, Reed Beds and Constructed Wetlands for Wastewater Treatment, Water Research Centre Publications, Swindon, UK, 1996.

[203] J. R. Kuipers, “Technology-based effluent limitations for coalbed methane produced wastewater discharges in the Powder River basin of Montana and Wyoming," Draft Report, Northern Plains Resource Council, Billings, Mont, USA, 2004.

[204] F. Sanders, S. Gustin, and P. Pucel, Natural Treatment of CBM Produced Water: Field Observations, CBM Associates, 2001.

[205] J. Bauder, The Role and Potential of Use Selected Plants, Plant Communities, Artificial, Constructed, and Natural Wetlands in Mitigation of Impaired Water for Riparian Zone Remediation, Montana State University, Water Quality \& Irrigation Management, Bozeman, Mont, USA, 2002.

[206] K. E. Lynch, "Agency collection activities: coalbed methane extraction sector survey," Survey Docket ID No. EPA-HQ-OW2006-0771, Trout Unlimited to EPA Docket Center, 2008.

[207] D. W. Erskine, P. W. Bergman, and D. L. Wacker, "Use of produced water for oil and gas drilling in the San Juan Basin," in Proceedings of the 9th Annual Petroleum Environmental Conference, Albuquerque, NM, USA, October 2002.

[208] A. J. Daniel, B. G. Langhus, and C. Patel, Technical Summary of Oil \& Gas Produced Water Treatment Technologies, NETL, 2005.

[209] P. Xu and J. E. Drewes, "Viability of nanofiltration and ultralow pressure reverse osmosis membranes for multi-beneficial use of methane produced water," Separation and Purification Technology, vol. 52, no. 1, pp. 67-76, 2006.

[210] S. S. Madaeni, "The application of membrane technology for water disinfection," Water Research, vol. 33, no. 2, pp. 301-308, 1999.

[211] R. Han, S. Zhang, D. Xing, and X. Jian, "Desalination of dye utilizing copoly(phthalazinone biphenyl ether sulfone) ultrafiltration membrane with low molecular weight cut-off," Journal of Membrane Science, vol. 358, no. 1-2, pp. 1-6, 2010.

[212] Y. He and Z. W. Jiang, "Technology review: treating oilfield wastewater," Filtration \& Separation, vol. 45, no. 5, pp. 14-16, 2008.

[213] T. Bilstad and E. Espedal, "Membrane separation of produced water," Water Science and Technology, vol. 34, no. 9, pp. 239-246, 1996.

[214] S. Judd and B. Jefferson, Membranes for Industrial Wastewater Recovery and Re-Use Oxford, Elsevier, Philadelphia, Pa, USA, 2013.

[215] C. Bellona and J. E. Drewes, Reuse of Produced Water Using Nanofiltration and Ultra-Low Pressure Reverse Osmosis to Meet Future Water Demands, Ground Water Protection Council, Oklahoma City, Okla, USA, 2015, http://www.gwpc.org/sites/ default/files/event-sessions/Jorge_Drewes_PWC2002_0.pdf.

[216] S. Mondal and S. R. Wickramasinghe, "Produced water treatment by nanofiltration and reverse osmosis membranes," Journal of Membrane Science, vol. 322, no. 1, pp. 162-170, 2008.

[217] R. S. Faibish and Y. Cohen, "Fouling and rejection behavior of ceramic and polymer-modified ceramic membranes for ultrafiltration of oil-in-water emulsions and microemulsions," Colloids and Surfaces A: Physicochemical and Engineering Aspects, vol. 191, no. 1-2, pp. 27-40, 2001.

[218] R. S. Faibish and Y. Cohen, "Fouling-resistant ceramicsupported polymer membranes for ultrafiltration of oil-inwater microemulsions," Journal of Membrane Science, vol. 185, no. 2, pp. 129-143, 2001. 
[219] K. Konieczny, M. Bodzek, and M. Rajca, "A coagulationMF system for water treatment using ceramic membranes," Desalination, vol. 198, no. 1-3, pp. 92-101, 2006.

[220] J. Boysen, "The freeze-thaw/evaporation (FTE) process for produced water treatment, disposal and beneficial uses," in Proceedings of the 14th Annual International Petroleum Environmental Conference, Houston, Tex, USA, 2007.

[221] M. Ebrahimi, D. Willershausen, K. S. Ashaghi et al., "Investigations on the use of different ceramic membranes for efficient oil-field produced water treatment," K-State Research Exchange, 2015, http://krex.k-state.edu/dspace/bitstream/handle/2097/3520/EbrahimiDesalination2010.pdf?sequence $=1$.

[222] A. Lobo, Á. Cambiella, J. M. Benito, C. Pazos, and J. Coca, "Ultrafiltration of oil-in-water emulsions with ceramic membranes: influence of $\mathrm{pH}$ and crossflow velocity," Journal of Membrane Science, vol. 278, no. 1-2, pp. 328-334, 2006.

[223] G. Gutiérrez, A. Lobo, D. Allende et al., "Influence of coagulant salt addition on the treatment of oil-in-water emulsions by centrifugation, ultrafiltration, and vacuum evaporation," Separation Science and Technology, vol. 43, no. 7, pp. 1884-1895, 2008.

[224] K. S. Spiegler and O. Kedem, "Thermodynamics of hyperfiltration (reverse osmosis): criteria for efficient membranes," Desalination, vol. 1, no. 4, pp. 311-326, 1966.

[225] W. Mark, The Guidebook to Membrane Desalination Technology: Reverse Osmosis, Nanofiltration and Hybrid Systems Process, Design, Applications and Economic, L'Aquila Desalination Publications, 1st edition, 2007.

[226] B. Nicolaisen and L. Lien, "Treating oil and gas produced water using membrane filtration technology," in Proceedings of the Produced Water Workshop, Aberdeen, UK, 2003.

[227] F. T. Tao, S. Curtice, R. D. Hobbs et al., "Conversion of oilfield produced water into an irrigation/drinking quality water," in Proceedings of the SPE/EPA Exploration and Production Environmental Conference, SPE-26003-MS, San Antonio, Tex, USA, March 1993.

[228] US Environmental Protection Agency, Onsite Wastewater Treatment and Disposal Systems Design Manual, US Environmental Protection Agency, Washington, DC, USA, 1980.

[229] D. Su, J. Wang, K. Liu, and D. Zhou, "Kinetic performance of oil-field produced water treatment by biological aerated filter," Chinese Journal of Chemical Engineering, vol. 15, no. 4, pp. 591594, 2007.

[230] H. L. Ball, "Nitrogen reduction in an on-site trickling filter/upflow filters wastewater treatment system," in Proceedings of the 7th International Symposium on Individual and Small Community Sewage Systems, American Society of Agricultural Engineers, Atlanta, Ga, USA, December 1994.

[231] W. Shi and M. M. Benjamin, "Membrane interactions with NOM and an adsorbent in a vibratory shear enhanced filtration process (VSEP) system," Journal of Membrane Science, vol. 312, no. 1-2, pp. 23-33, 2008.

[232] A. I. Zouboulis and M. D. Petala, "Performance of VSEP vibratory membrane filtration system during the treatment of landfill leachates," Desalination, vol. 222, no. 1-3, pp. 165-175, 2008.

[233] V. Piemonte, M. Prisciandaro, L. di Paola, and D. Barba, "Membrane processes for the treatment of produced waters," Chemical Engineering Transactions, vol. 43, 2015.

[234] O. A. Hamed, "Evolutionary developments of thermal desalination plants in the Arab gulf region," in Proceedings of the Beirut Conference, Beirut, Lebanon, June 2004, http://www
.researchgate.net/publication/228945604_Evolutionary_developments_of_thermal_desalination_plants_in_the_Arab_Gulf_ region.

[235] United States Bureau of Reclamation, Desalting Handbook for Planners, Desalination and Water Purification Research and Development Program Report no. 72, United States Department of the Interior, Bureau of Reclamation, Washington, DC, USA, 3rd edition, 2003.

[236] GWI, IDA Worldwide Desalting Plants Inventory Report no. 19 (Global water intelligence) Gnarrenburg, Germany, 2006.

[237] A. D. Khawaji, I. K. Kutubkhanah, and J.-M. Wie, "Advances in seawater desalination technologies," Desalination, vol. 221, no. 1-3, pp. 47-69, 2008.

[238] B. Heins, World's First SAGB Facility Using Evaporators, Drum Boilers, and Zero Discharge Crystallizers to Treat Produced Water, Efficiency and Innovation Forum for Oil Patch, Calgary, Canada, 2005.

[239] J. Brandt, Business is Booming for Fracking Wastewater, Fierce Water, 2015.

[240] J. E. Boysen, J. A. Harju, B. Shaw et al., "The current status of commercial deployment of the freeze thaw evaporation treatment of produced water," in Proceedings of the SPE/EPA Exploration and Production Environmental Conference, SPE52700-MS, pp. 1-3, Austin, Tex, USA, March 1999.

[241] AltelaRain TM System ARS-4000, New Patented Technology for Cleaning Produced Water On-Site, Altela Information, 2007.

[242] N. A. Godshall, "AltelaRain ${ }^{\text {SM }}$ produced water treatment technology: making water from waste," in Proceedings of the International Petroleum Environmental Conference (IPEC '06), pp. 1-9, ALTELATM, San Antonio, Tex, USA, October 2006.

[243] Jain Irrigation Systems, Sand Separator-Jain Hydro Cyclone Filter, Jain Irrigation Systems, Jalgaon, India, 2010.

[244] A. L. Cassidy, "Advances in flotation unit design for produced water treatment," in Proceedings of the Production Operations Symposium, SPE-25472-MS, pp. 21-23, Oklahoma City, Okla, USA, March 1993.

[245] M. Çakmakce, N. Kayaalp, and I. Koyuncu, "Desalination of produced water from oil production fields by membrane processes," Desalination, vol. 222, no. 1-3, pp. 176-186, 2008.

[246] F. R. Spellman, Handbook of Water and Wastewater Treatment Plant Operations, CRC Press, Boca Raton, Fla, USA, 2003.

[247] D. A. Clifford, "Ion exchange and inorganic adsorption," in Water Quality and Treatment, R. D. Letterman, Ed., McGrawHill, New York, NY, USA, 1999.

[248] D. T. Meijer and C. Madin, "Removal of dissolved and dispersed hydrocarbons from oil and gas produced water with mppe technology to reduce toxicity and allow water reuse," APPEA Journal, pp. 1-11, 2010.

[249] H. M. Pars and D. T. Meijer, "Removal of dissolved hydrocarbons from production water by macro porous polymer extraction (MPPE)," in Proceedings of the SPE International Conference on Health, Safety, and Environment in Oil and Gas Exploration and Production, SPE-46577-MS, Society of Petroleum Engineers, Caracas, Venezuela, June 1998. 

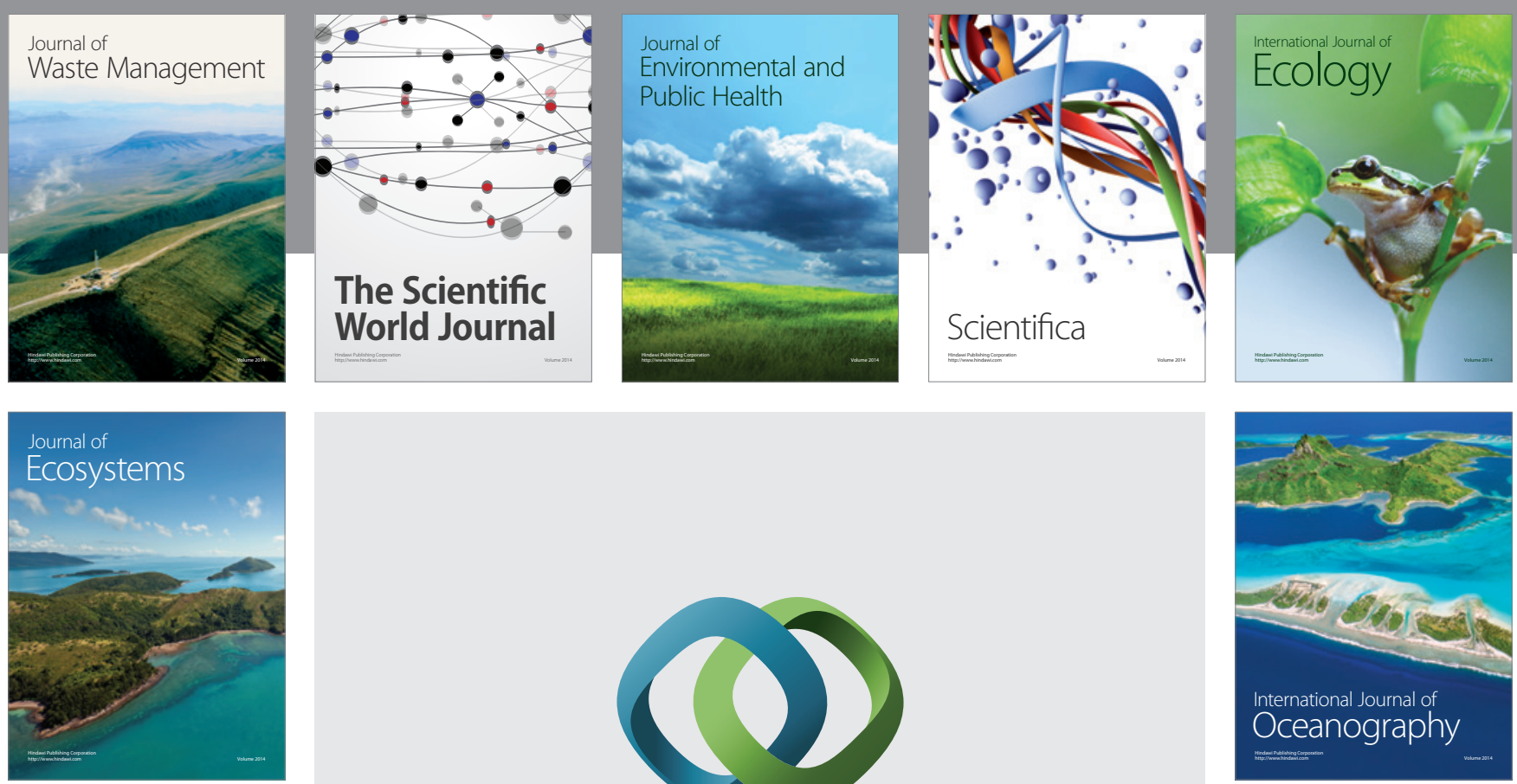

The Scientific World Journal
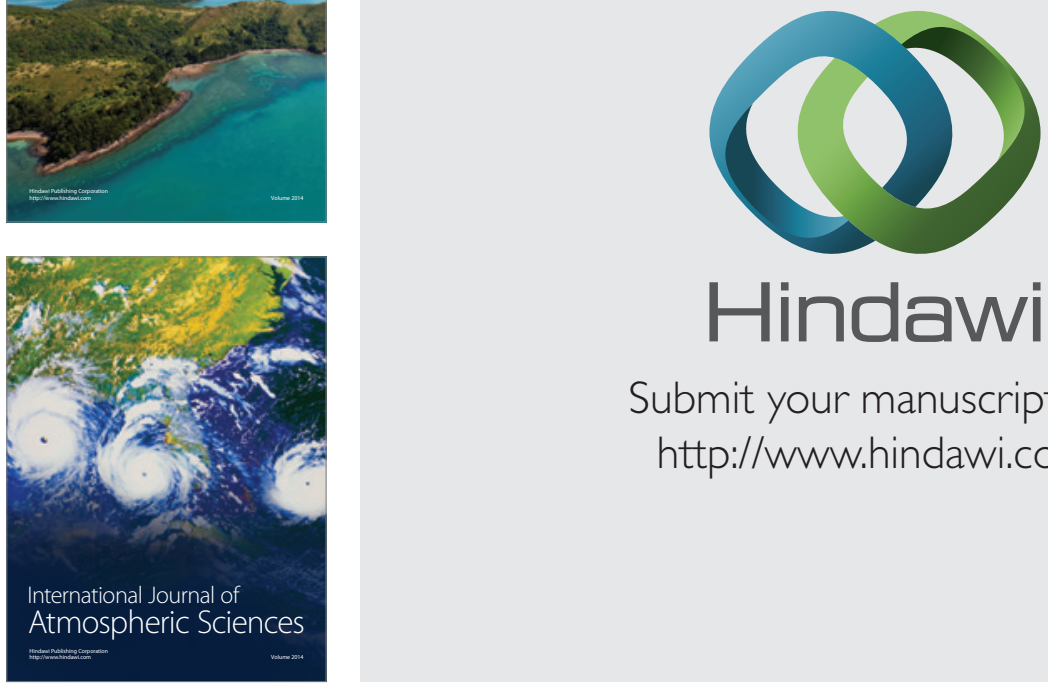

\section{Hindawi}

Submit your manuscripts at

http://www.hindawi.com
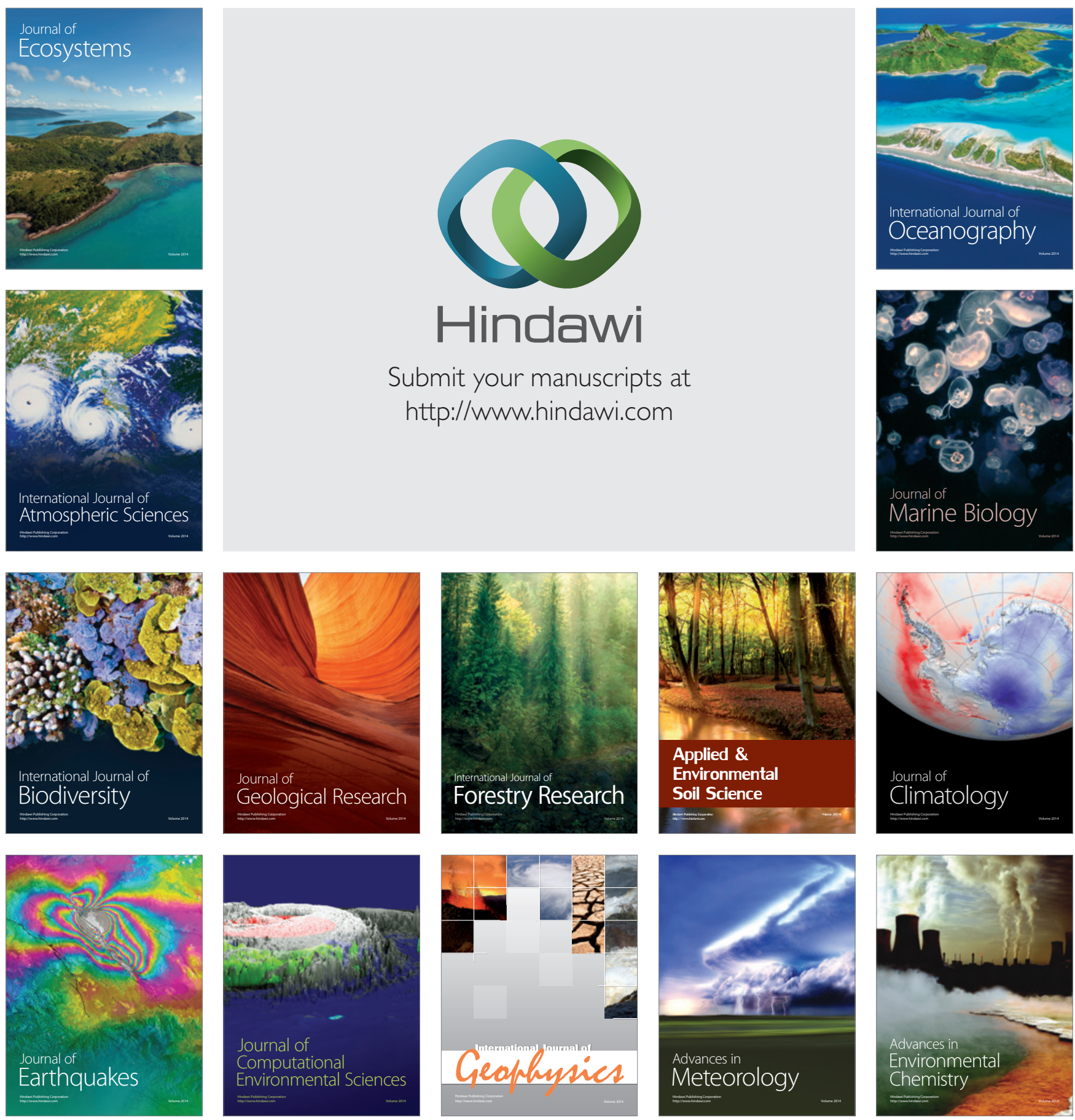